\title{
Property Rights, Collateral, Creditor Rights, and Insolvency in East Asia'
}

\author{
Douglas W. Arner, Charles D. Booth, "* Paul Lejot***, \& Berry \\ F. C. $\mathrm{HSU}^{* * * *}$
}

SUMMARY

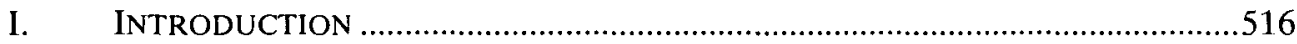

II. GOVERNANCE, ECONOMIC AND LEGAL SYSTEMS .....................................518

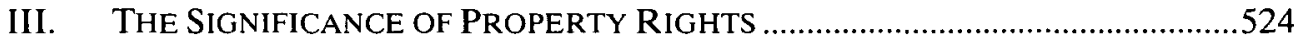

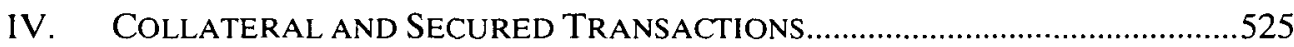

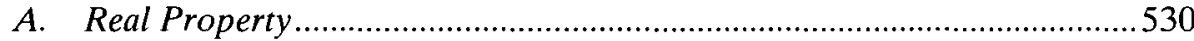

B. International Standards for Movables.................................................. 531

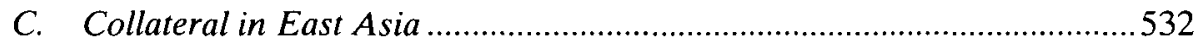

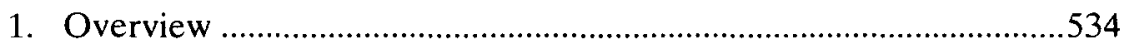

2. Real Property .........................................................................555

3. Movables and Unsecured Property ................................................538

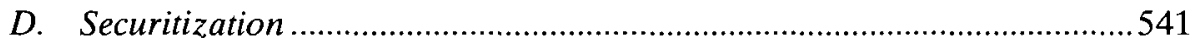

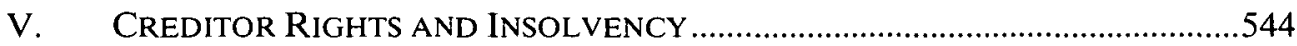

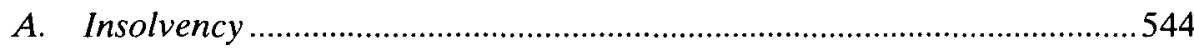

B. Interaction between Creditor Rights and Insolvency .........................546

1. This is an expanded and updated version of a study that was published as Douglas W. Arner, Charles D. Booth, Berry F. C. Hsu, Paul Lejot, Qiao Liu \& Frederik Pretorius, Property Rights, Collateral and Creditor Rights in East Asia, in EAST ASIAN FINANCE: SELECTED IsSUES (Ismail Dalla ed., World Bank 2006). The authors thank Dean Polizzotto of the Asian Institute of International Financial Law of the Faculty of Law of the University of Hong Kong for research assistance, and the Hong Kong Research Grants Council Competitive Earmarked Research Grant program and the University of Hong Kong Strategic Research Areas initiative for financial support.

- Associate Professor; Director, Asian Institute of International Financial Law (AIIFL); \& Director, LLM (Corporate \& Financial Law) Program, Faculty of Law, University of Hong Kong.

* Professor \& Director, Institute of Asian-Pacific Business Law, William S. Richardson School of Law, University of Hawai i at Manoa.

*.* Visiting Fellow, AIIFL, Faculty of Law, University of Hong Kong; \& Visiting Research Fellow, ICMA Centre, University of Reading.

*.** Associate Professor, Faculty of Architecture, \& Deputy Director, AIIFL, Faculty of Law, University of Hong Kong. 
C. Creditor Rights and Insolvency in East Asia .....................................547

1. Insolvency: Pre-1997 Overview.....................................................548

2. Insolvency: Post-Financial Crisis Legal Reforms ..........................551

3. Insolvency: Post-Financial Crisis Out-of-Court Reforms................554

4. Interaction between Creditor Rights and Insolvency .....................556

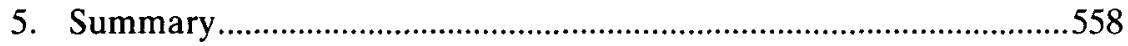

VI. CONTRACT ENFORCEMENT AND DiSPUTE RESOLUTION ...............................559

\section{INTRODUCTION}

A number of common preconditions must prevail if a market-orientated financial system or national economy is to develop and function effectively. ${ }^{2}$ Those relating to financial sector development rest on three principles: the first, institutional and legal; the second, largely legal; and the third, related mainly to policy.

First, a market economy and a market-based financial system cannot exist if certain institutional and legal supports are not in place, namely, a governance mechanism that establishes property rights and provides for the consistent enforcement of contracts and resolution of commercial disputes. It is also important that the setting provides for the development of human capital. ${ }^{3}$

With these institutional foundations in place, a number of legal underpinnings must then be available for a market-based financial system to function effectively. These include the availability of collateral to support secured transactions, a system of law for the establishment and dissolution of corporate bodies, and a transparent system of government funding, including taxation. To maintain such effectiveness, national and sub-national governance should also provide more widely for the rule of law, which is taken to be transparent and non-discriminatory, in addition to establishing specific property rights, enforcing contracts and supporting commercial dispute resolution.

Third, a financial sector functions most effectively in the context of appropriate macroeconomic policies. These policies, while largely outside legal and institutional concerns, operate best in the context of an appropriately designed and transparent institutional framework.

No sophisticated market economy or market-based financial system can exist without these prerequisites, regardless of indigenous or acquired national characteristics or the form manifested by that system. In this context, this article examines the relationships within East Asia between economic development, governance, property rights, provisions for the deployment of collateral and the creation of secured financial transactions, and creditor rights and their relationship with insolvency.

2. The framework of analysis underlying this study is based upon DOUGLAS W. ARNER, FINANCIAL STABILITY, ECONOMIC GROWTH AND THE ROLE OF LAW (2007).

3. Human capital development is not examined here. It became an acknowledged feature of growth studies with Lucas's 1985 Marshall lectures. See Robert E. Lucas, Jr., On the Mechanics of Economic Development, 22 J. MONETARY ECON. 1, 17 (1988). 
The eleven subject jurisdictions appear in two groups, shown in Table 1. First is a core group of nine, which have undergone, or intend to enact, reforms in the subject areas. Second are two common law jurisdictions that are perceived as being among the most sophisticated in the region in terms of the issues examined, and which may represent benchmarks for reform elsewhere. It is not suggested that either jurisdiction represents an institutional or practical optimum. ${ }^{4}$

TABLE 1: JURISDICTION CLASSIFICATIONS

\begin{tabular}{lll}
\hline \multicolumn{2}{c}{ Study Core } & Regional Benchmarks \\
Jurisdictions & Hong Kong \\
\hline Cambodia & South Korea & Singapore \\
China & Taiwan & \\
Indonesia & Thailand & \\
Malaysia & Vietnam & \\
Philippines & & \\
\hline
\end{tabular}

Neither law nor practice is advanced in relevant areas in most of the remaining jurisdictions within the region, but the issues addressed in this article have begun to receive attention from policymakers and commercial interests. The issues of policy and principle raised in this article have been regularly debated in official and legal circles since the economic and social shocks associated with the 1997-98 Asian financial crisis. In no national case can the legal, regulatory, or policy background be described as either complete or fully integrated, even in the two examples of benchmarks, or elsewhere in countries where specific reforms have been recently instigated or completed, for example, China or the Philippines.

Later sections include tables that give appraisals of the legal framework for creditor rights, especially in relation to secured claims; the effectiveness of national insolvency systems; specific or general provisions for private securitized transactions; and the mutual compatibility of systems for enforcement. Thus in Tables 2, 5, 7 and 8 , a scale rising from 1 to 5 is used to indicate the quality or effectiveness of specific factors that are self-explanatory, with "NA" used to signify where the law makes no provision in a specified matter, based primarily upon qualitative analysis. Unless stated, these tables use terms such as "security" and "interest" in a generic sense without attachment to any legal system or jurisdiction. In each case, the appraisals acknowledge not only pure aspects of law and regulation (often clear where the law includes recent legislation), but also qualifications to reflect enforcement issues, integration with related law, and the stability of the regulatory setting. Commercial participants throughout the region have often found that while the law appears clear, it suffers from uncertain application. The results appear in complex private financial transactions that seek to mitigate such risks.

It is now generally accepted that the form and practice of law influences economic behavior. In particular, institutional quality is an important determinant of

4. Certain reforms in Japan's civil code and statutes have guided changes elsewhere among civil law jurisdictions in the study group. See infra note 80 . 
credit creation and flows of capital, both among the main sectors of an economy and in cross-border savings and investment. Factors such as legal origin, the nature of the acquisition or founding of law, and details of its application and enforcement are seen in features of governance, economic systems and structure, commercial culture, corporate behavior, and financing patterns. These conditions also affect broader variables such as national output or personal income. The appraisals in this article and the research upon which they are based thus adopt the view of users, that is, principals and agents, that become subject to the law rather than those involved in its creation or administration.

At the same time, the efficiency and consistency of the law's operation will always form part of its institutional costs, so that no assessment can ignore the organization and management of legal systems. This is especially valid in the context of creditor claims and corporate distress. In general, the main objective of the reform of laws governing security and creditor rights will be to influence behavior through changes in costs. The following two parts of this article discuss respectively, its theoretical background and the role of property rights in transaction formation and credit creation. Parts IV and $V$ then examine collateral and secured transactions, and creditor rights and insolvency, respectively. Part VI concludes with an outline of provisions in Asia for contract enforcement and commercial dispute resolution.

\section{GOVERNANCE, ECONOMIC AND LEGAL SYSTEMS}

State governance and the appropriateness of political and economic structure have been of interest for over ten thousand years, prompted by specialized human activity encouraging the first agricultural settlements. This in turn allowed the development of writing systems appropriate and necessary to sustain the administrative structures of such settlements. Building the "perfect society" and creating governance systems to encourage its development has been a focus of many thinkers, including Confucius, Plato, Aquinas, Locke, and Marx. All political and economic systems function in close parallel, even though the interplay may not always be acknowledged by political theorists. Certainly, the relationship between politics (or governance) and economics has been a central interest of Smith, Marx, and more recently Keynes, Hayek, and Friedman. Although politics and economics became increasingly distinct disciplines in the twentieth century, the end of the millennium saw a reviving interaction between governance and economics, partly encouraged by the experience of market orientation undertaken by many centrally planned economies, and from the conspicuous failure of earlier economic development models in neglecting institutional issues of governance.

The role and development of financial intermediaries have become a focus of attention only recently in law, financial policy, and economics, although each discipline is directly concerned with both the problem and its several explanations. Similarly, conditions influencing how financial structure develops have begun to interest scholars in the developed and developing world, and those helping to create supportive policy. Until the 1970s few economic or finance theorists gave attention to the nature of financial systems or how they may affect economic development. Similarly, the importance and influence of the characteristics of financial markets and intermediaries has been accepted only since the late-1980s, with the inception and success of the law and finance and institutional economics schools. Financial 
intermediation is now recognized as vital to many aspects of economic development, and what determines the nature of financial intermediaries and financial system infrastructure is susceptible to both quantitative analysis and the tools of legal and economic theory.

By the beginning of the $1990 \mathrm{~s}$, two traditionally polar alternatives-central planning under state ownership and laissez-faire-had been subsumed into an apparent consensus as to the general superiority of a market economy, but one functioning under the framework of an appropriate and transparent regulatory system, with the state taking a benign but active role in addressing the interests of any society through the provision of largely agreed public goods, systems to limit or ameliorate market failure, and sanctions to penalize market abuse, whether arising from monopoly or the occurrence of asymmetric information available to privileged participants. Nonetheless, as Shleifer and others have recognized, many differences remain among today's economic and governance models. ${ }^{5}$ The question then arises as to what may represent the best choices among available options, and to what extent those choices lead to the disadvantage of certain interests.

For institutional economists such as North, and writers in the law and economics school, governance systems must provide for two fundamental features to support a market economy, regardless of its ideological identity and consequent form. First, the system must provide for clear and usable property rights. Second, it must facilitate practical and fair contract enforcement. Both literatures agree that these conditions are essential in the context of imperfect markets where there exist discernable transaction costs. While there appears to be agreement as to the need to satisfy these basic points, the governance structure that best supports a market economy is less apparent, and may change in relation to the relative development of the host economy.

Many scholars have argued further that democratic models of governance are optimal in protecting property rights and enforcing contracts, albeit this was the result they sought most often to prove. However, Olson has presented a convincing argument that a variety of governance structures can provide each of these necessary features. ${ }^{6}$ Specifically, he suggested that an autocrat with a long-term time horizon will have a strong incentive to support both property rights and contract enforcement in order chiefly to maximize revenue from taxation. ${ }^{7}$ Conversely, Olson argues that any democracy, while potentially providing for property rights and the enforcement of contracts, may nevertheless become subject to inefficient outcomes due to its responsiveness to representative but factional interests. ${ }^{8}$ Thus neither autocracy nor democracy is necessarily a superior political system in providing the most beneficial support for a market economy. Instead, what is necessary is a "market-augmenting government." There is contemporary anecdotal evidence that

5. See Simeon Djankov et al., The New Comparative Economics, 31 J. CoMP. ECON. 595 (2003).

6. MANCUR OlSON, POWER AND PROSPERITY: OUTGROWING COMMUNIST AND CAPITALIST DICTATORSHIPS (2000).

7. Id.

8. Id.

9. Charles Cadwell, Foreword to MANCUR OLSON, Outgrowing COMMUNIST AND CAPITALIST DictATORSHIPS, at $\mathrm{x}$ (2000). 
certainly supports Olson's theory, ${ }^{10}$ and recent empirical research has begun to test these ideas and appears to be supportive. ${ }^{11}$

North sums up the interaction between the political system and property rights thus:

Broadly speaking, political rules in place lead to economic rules, though the causality runs both ways. That is, property rights and hence individual contracts are specified and enforced by political decision-making, but the structure of economic interests will also influence the political structure. In equilibrium, a given structure of property rights (and their enforcement) will be consistent with a particular set of political rules (and their enforcement). Changes in one will induce changes in the other. ${ }^{12}$

The result is that a national governance structure is important and must provide for property rights and the enforcement of contracts, as well as human capital development. However, while some governance structures are clearly not conducive to liberty (any state run by the myopic autocrat-bandit), there is at present no clearly preferable model. Both autocratic and democratic governance systems can support a market economy. Similarly, each can provide for institutional choices that fail to result in efficient, wealth-maximizing outcomes in a given economy.

Two further underlying issues are present throughout this study: those relating to the mechanisms that transmit influences on economic growth, and those involving the means by which finance affects economic development, including the relationship between legal systems and financial structure. Neoclassical economic theory, post-1940s growth theories and traditional finance theory all ignore or assume away the nature of financial systems. ${ }^{13}$ While finance and corporate finance theory examine commercial organizations in terms of contract or cost, a similar approach has been applied only recently to financial intermediaries, and rarely to examine financial systems. Thus, early modern studies of the determinants of economic growth identified a strong correlation between the "rule of law" and per capita growth. ${ }^{14}$ These analyses were weak in terms of identifying with any practical precision the ways in which legal reform might be invoked to promote growth, given

10. Cf. China, Singapore.

11. See Djankov et al., supra note 5 (indicating that policies are more important than democratic institutions, and specifically, that human capital is a more basic source of growth than democratic institutions; that poorer states can alleviate poverty through sound policies, even when pursued by dictators; democratic institutions are developed after economic "take-off").

12. DOUglass C. NORTh, Institutions, Institutional Change, AND ECONOMiC PERFormanCE $48(1990)$.

13. This growth school pattern probably began with WALTER ROSTOW, THE PROCESS OF ECONOMIC GROWTH (1952); Lucas, supra note 3, perhaps the most willful financial agnostic, based indifference upon the thesis that at firm level, financial performance is unrelated to the composition of funding. Certain Marxian analysis asserts a causal relationship running from economic activity to financial structure to accord with the primacy of capitalist production. It is often unspecific in its treatment of both law and financial activity in this area, perhaps reflecting Marx's disdain for "merchant" or "commercial" capital; an exception is J. J. McManus The Emergence and Non-emergence of Law, 5 BRIT. J. LAW \& SOC'Y 185, 190 (1978) (describing the origin of English consumer credit legislation).

14. Notably, Robert J. Barro, Economic Growth in a Cross Section of Countries, 106 Q. J. ECON. 26-28 (1971); RoBert J. BARRo, DETERMINANTS OF ECONOMIC GROWTH: A CROSS-COUNTRY EMPIRICAL STUDY 26-28 (1997). 
that the measures used to specify rule of law explanatory variables were primitive and included subjective components such as commercial indexes of sovereign risk.

The law and finance school asserts that there exist significant causal links between the origins of law or the means by which a national system of law is acquired, and the nature of financial system development. ${ }^{15}$ Certain scholars further suggest a causal relationship that flows from financial development to economic performance, although most accept that such links are unlikely to be unicausal. ${ }^{16}$ Questions investigated or prompted by the law and finance school include: first, the relationship of institutional development to general economic welfare; second, the relationship between legal origin and the effectiveness and even-handedness of legal systems; third, whether the effectiveness of a national legal system is significantly determined by its origin or the form of its acquisition; and finally, whether common law is inherently more effective than other systems in encouraging financial development, stimulating credit growth or protecting property rights. ${ }^{17}$

While the general premise of law and finance protagonists has become accepted, especially in suggesting more specific legal research agendas, the school has been criticized for two main methodological reasons. The first is its choice and specification of explanatory variables: ${ }^{18}$ which may either be incomplete or endogenously related to the objective questions that the analysis seeks to answer; ${ }^{19}$ which may not signify close substitutes or take account of compensatory mechanisms in different legal systems; $;^{20}$ or may reflect customary choice appropriate mainly to

15. Djankov et al., supra note 5; Robert G. King \& Ross Levine, Finance \& Growth: Schumpeter Might Be Right, 108 Q. J. ECON. 717 (1993), Ross Levine, Finance \& Growth: Theory \& Evidence (Nat'l Bureau of Econ. Res. Working Paper No. 10766, 2004); Ross Levine, Financial Development and Economic Growth: Views and Agenda, 35 J. ECON. LIT. 688 (1997); Raghuram G. Rajan \& Luigi Zingales, Financial Systems, Industrial Structure, and Growth, 17 OXFORD REV. ECON. POL. 467 (2001).

16. Notably Thorsten Beck et al., Law and Finance: Why Does Legal Origin Matter? (World Bank Pol'y Res. Working Paper 2904, 2002); Thorsten Beck \& Ross Levine, Legal Institutions and Financial Development (Nat'l Bureau of Econ. Res. Working Paper No. 10126, 2003); Rafael La Porta et al., Law and Finance, 106 J. POL. ECON. 1113 (1998); Legal Determinants of External Finance, 52 J. FIN. 1131 (1997); Paul G. Mahoney, The Common Law and Economic Analysis: Hayek Might be Right, $30 \mathrm{~J}$. LEGAL STUD. 503 (2001); Peter L. Rousseau \& Richard Sylla, Financial Systems, Economic Growth and Globalization (Nat'l Bureau of Econ. Res. Working Paper No. 8323, 2001).

17. Given that the quality of creditor and shareholder protection measures the effectiveness of a national legal system. This is not synonymous with financial development but is often so taken, with the protection of claims used as a proxy for financial sophistication.

18. Philip Arestis \& Panicos Demetriadis, Financial Development \& Economic Growth: Assessing the Evidence, 107 ECON. J. 783 (1997); Daniel Berkowitz et al., The Transplant Effect, 51 AM. J. COMP. L. 163 (2003); David Blum et al., The Financial-Real Sector Nexus: Theory \& Empirical Evidence (Res. Inst. for European Affairs Working Paper No. 43, 2002); Charles Kenny \& David Williams, What do we know about Economic Growth? Or, Why don't we know very much?, 29 WORLD DEV. 1 (2001); Michael Thiel, Finance \& Economic Growth: A Review of Theory \& the Available Evidence (Eur. Comm. Econ. Pap. No. 158, 2001); Paul Wachtel, How much do we really know about Growth \& Finance?, 88 FED. RES. BANK Atlanta ECON. Rev. 1 (2003).

19. See Rajan, supra note 15.

20. Mark J. Roe, Strong Managers, Weak OWners: The Political Roots of american Corporate Finance (1994); Katharina Pistor \& Philip Wellons, THE Role of law and LeGal INSTITUTIONS IN ASIAN ECONOMIC DEVELOPMENT 1960-1995 (1999); Katharina Pistor et al., Law and Finance in Transition Economies, (European Bank for Reconstruction \& Dev. Working Paper No. 48, 2000); Sofie Cools, The Real Difference in Corporate Law Between the United States and Continental Europe: Distribution or Powers, 30 DEL. J. CORP. L. 697 (2005); Mathias Siems, Legal Origins: Reconciling Law \& Finance And Comparative Law, available at SSRN: http://ssrn.com/abstract=920690. 
developed, homogenous markets. ${ }^{21}$ The second attack concerns the usefulness of the school's conclusions in indicating legal or regulatory reform, given that legal related explanatory variables have of necessity been general and unspecific. ${ }^{22}$

As examples, the scale of finance evident in an economy has often been used as an explanatory variable, but it may not measure financial sophistication, contrary to the intentions of La Porta, López-de-Silanes, Shleifer \& Vishny (LLSV) or Rousseau $\&$ Sylla ${ }^{23}$ no distinction is made between types of claims against a debtor or firm. Rather, all debt is generally taken as secured. The chain of causation identified by the law and finance school (especially LLSV) runs from legal origin to enforcement, to financial development and finally to growth. This is unreliable for policy development if legality impacts growth but legal origin does not impact legality. A more fully informed identification of explanatory variables will assist with these problems. It may also overcome problems caused by the static nature of the law and finance school's analysis, for example, ignoring the convergence of civil and common commercial law with political regionalization and financial harmonization, more extensive financial and trade treaty networks, and the activity of international selfregulatory bodies.

Theoretical interest in the structure and operation of financial systems was largely absent from legal and financial studies before the 1970s, and in schools of economics was confined to political economy. ${ }^{24}$ That such indifference has vanished results largely from the influence of two trains of scholars. First, Goldsmith sought ways to test whether financial structure could be related to levels of economic development. ${ }^{25}$ This work was to become a foundation of the law and finance school. Second, North and others synthesized hitherto separate concepts from law, finance and economics in what has become modern institutional economics, which stresses the nature and effect of core rights, duties and incentives. While the first is primarily concerned with whole markets or national economies and the latter is initially microeconomic in its emphasis, the two disciplines share certain interests, and meet in the analysis of the effects of legal systems and property rights, for example, on economic conditions and development.

The approach of the traditional financial development school was to examine the role of banking and bank credit creation. More recent law and finance analysis has taken account of environmental and cultural factors, and indeed all measurable financial variables. None has yet examined in detail the quality of law enforcement in a commercial context, for example, in the willingness of national courts to enforce foreign judgments and accept non-exclusive jurisdiction transaction provisions. Instead, where quality of law and regulation is included in analysis, its tendency to date has been on subjective index measures of the "rule of law." In addition, while law and finance scholars have sought to quantify the effects on financial

21. Naomi R. Lamoreaux \& Jean-Lamoreaux Rosenthal, Legal Regime and Business Organizational Choice: A Comparison of France and the United States (Nat'l Bureau of Econ. Res. Working Paper No. 10288, 2004).

22. Frank B. Cross, Law and Economic Growth, 80 TEX. L. REV. 1736 (2002); Kevin E. Davis, What Can the Rule of Law Variable Tell Us About Rule of Law Reforms? (N.Y.U. L. \& Econ. Res. Paper Series Working Paper No. 04-026, 2004); Kevin E. Davis \& Michael J. Trebilcock, Legal Reforms and Development, 22 THIRD WORLD Q. 210 (2001); Roe, supra note 20.

23. See supra note 16.

24. Due largely to Marx, Schumpeter, and Weber and their later acolytes, but in no instance with the dedication to detail of the modern law and finance school.

25. RAYMOND GOLDSMITH, FINANCIAL STRUCTURE AND DEVELOPMENT (1969). 
development of national legal systems or their origins, ${ }^{26}$ no systematic attempt has yet appeared in this context that together considers legal origins, their form of acquisition and the distinct nature of jurisdictions, especially when their roots are mixed. ${ }^{27}$ Nor has analysis yet recognized that the nature of commercial legal disputes may itself be endogenous to the legal system.

Related work includes a considerable body of empirical studies in the style pioneered by Goldsmith and following the methods adopted by King \& Levine and LLSV in seeking evidence of causal relationships between financial market or institutional sophistication or structure (including legal origins and conditions), and economic development, commonly measured by growth in national output. While not unanimous, these generally suggest that finance often has a positive effect on growth, although contrary to popular belief there is no theoretical school that asserts the contrary: that the primary causal flow is from economic growth to financial development. $^{28}$

The remainder of this article contains summaries of appraisals of the effectiveness of current law and practice as to collateral and creditor rights in eleven prominent East Asian jurisdictions. In particular, it examines discrete aspects of the creation and treatment of secured creditor interests, processes for insolvency, securitization, and the functional relationship between these related aspects of law. The effects of globalization on both market practice and harmonization of financial regulation mean that the private law governing international financial transactions differs less by virtue of the location of parties or the place of transaction execution than by issues of judicial enforcement, including the willingness of courts to provide equitable and predictable judgments to domestic and foreign creditors. ${ }^{29}$ The quality of legal and practical provisions for insolvency is also central to the willingness of lenders and investors to provide funds for capital investment. By contrast, legal frameworks for the taking or enforcement of collateral may be influenced by informal or traditional national or local commercial custom, although remaining subject also to the prevailing form of law and the roots of national law.

26. See La Porta et al., supra note 16 (classifying forty-nine national legal systems by their origins in English common law or French, German or "Scandinavian" civil law); Berkowitz et al., supra note 18 (dividing the same sample among ten original systems); PHILIP WOOD, COMPARATIVE FINANCIAL LAW (1995) (perceiving seven categories, not including states that lack a clear legal system or for which it may be "emerging"). Earlier comparatists found different solutions, the most contemporary being David, who identifies eight "families" of law, see RENÉ DAVID \& JOHN E. C. BRIERLEY, MAJOR LEGAL SYSTEMS IN THE WORLD TODAY: AN INTRODUCTION TO THE COMPARATIVE STUDY OF LAW (John E. C. Brierley trans., $2 d$ ed. 1978), not all of which subsist in the form described.

27. Philip Wood, Global Law Maps: Key Map of Jurisdictions (mimeo, 2001) identified up to 307 distinct national and state jurisdictions. The number is certain to change.

28. That a body of scholarship contends that financial development largely responds to economic growth was first suggested against the theme of his study by Richard C. Porter, The Promotion of the "Banking Habit" and Economic Development, 2 J. DEV. STUD. 346, 363 (1966) (asserting in a footnote that "the few economists who have proposed a clear direction of causation between real and financial growth usually suggest [that real growth precedes financial sector development]"). The remark is often repeated without substantiation.

29. This appears in contemporary comparative analyses of commercial law. See WoOD, supra note 26. 


\section{The SignificANCE of Property RightS}

Property rights were an important concern for Smith, Marx and Weber but received little attention from economists for generations until becoming subject to intensive research in the late 1970s. Until recently the nature of finance and thus the preconditions for its provision were ignored or assumed away by generations of economists and finance specialists; only "maverick" opinion appears to have considered otherwise.

The importance of property rights began to receive significant contemporary attention when the disintegration of the Soviet bloc introduced the challenge of transforming command economies to market-based systems. Development specialist de Soto deserves considerable credit for increasing awareness of the importance of property rights in this respect, especially in relation to the potential impact of formally endowing individuals with such rights.

Classically, property is seen as a "bundle of rights." More specifically, "property" includes some or all of a variety of different "rights," including the rights to hold, use, modify, transfer, or destroy a real or intangible asset. Questions of degree and time relate to all such varied rights, and the extent to which a property owner may exploit such rights may be constrained by the competing rights of others within a legal system or as part of public policy. In addition, property can be real or personal, tangible, or intangible. The more complex a system of property rights, the more effective is their potential use in the context of finance and capital-raising.

According to North:

Property rights are the rights individuals appropriate over their own labor and the goods and services they possess. Appropriation is a function of legal rules, organizational forms, enforcement, and norms of behaviorthat is, the institutional framework..$^{30}$

De Soto argues that capital is the engine of a market economy, with property rights the mechanism that allows it to be effectively deployed. ${ }^{31}$ Further, relatively poor countries often fail to produce capital sufficient for economic development due to five main failings in property systems. First, such societies may have substantial masses of capital, ${ }^{32}$ yet it represents "dead" resources in that it is constituted by assets, interests or claims that cannot be used or mobilized as capital. Second, capital is intrinsically difficult to define or recognize. Third, many states have neglected the importance of the preceding two factors, an attitude that has begun only slowly to change. ${ }^{33}$ Fourth, while de Soto's process of mobilizing property rights

30. Douglass North, InStitutions, InStitutional CHANGE AND ECONOMiC PERFormanCE 33 (1990).

31. Hernando de Soto, The Mystery of Capital: Why Capitalism Triumphs in the WeST AND FAILS EVERYWHERE ELSE (2000).

32. Id. at 35. By his calculation, "the total value of the real estate held but not legally owned by the poor of the Third World and former communist nations is at least [US]\$ 9.3 trillion." Id.

33. De Soto states this best:

The substantial increase of capital in the West over the past two centuries is the consequence of gradually improving property systems, which allowed economic agents to discover and realize the potential in their assets, and thus to be in a position to produce the non-inflationary money with which to finance and generate additional production. 
needed in emerging or transition economies had occurred earlier elsewhere, it was often poorly understood or documented, even in relatively sophisticated states. Finally, laws need to reflect national or local circumstances in order to allow the effective transformation of property rights into capital.

For de Soto:

A well-integrated legal property system in essence does two things: First, it tremendously reduces the costs of knowing the economic qualities of assets by representing them in a way that our senses can pick up quickly; and second, it facilitates the capacity to agree on how to use assets to create further production and increase the division of labor. ${ }^{34}$

De Soto concludes that formal property systems are required to produce six effects so as to allow individuals to generate usable capital. These are: first, making certain the economic potential of existing assets; second, integrating dispersed information into a single dependable system; third, making individuals accountable for their economic actions; fourth, increasing the fungibility of assets; fifth, marshalling individuals into valuable social networks; and sixth, protecting the integrity of legitimate transactions. ${ }^{35}$

Established and accepted property rights and their identification and protection, including rights over intellectual property are, therefore, essential in any market economy. ${ }^{36}$ Unfortunately, de Soto notes that such rights have evolved in advanced economies over protracted periods, making it difficult even for the legal historian to discern how they function or become established. Without complete templates of this kind it may never be simple for emerging, transition or developing economies to introduce those experiences or systems, even when respecting the integrity of local or state culture. Furthermore, the recognition of property rights is not self-justifying; the need is for such rights to be available for use other than in instantly completed transactions. This is an underlying theme of the remainder of this article.

\section{Collateral and Secured Transactions}

Collateral exists to meet commercial customs, national practices, and socioeconomic constraints that differ strongly between jurisdictions, even in an era when commercial practice and financial regulation are often well-integrated and the international harmonization of financial markets is well-advanced. Several World Bank studies have surveyed law, institutions, and secured transactions, ${ }^{37}$ but the reasons for security differ everywhere by intention, nature, and degree. This affects whether the granting of collateral is an efficient choice for commercial or individual

Id. at 65 .

34. Id. at 63 .

35. Id. at $49-62$.

36. Leora Klapper et al., Business Environment and Firm Entry: Evidence from International Data 27 28 (World Bank Policy Research, Working Paper No. 3232, 2004).

37. See World Bank, 1989 World Bank Dev. Rep. (1989); 2002 World Bank Dev. Rep. (2002); Yoram Keinan, The Evolution of Secured Transaction's Background Study for World Development Report 2002 (2001). 
borrowers, or for creditors at large. Recent analysis of European transition economies suggests that the provision of collateral is important in inducing earlystage development. ${ }^{38}$

Schumpeter's 1939 description of the working of capitalism ${ }^{39}$ draws on his earlier theoretical approach to interest and credit creation that came to be disputed by contemporary traditional classicists (Cannan), radicals (Keynes and Joan Robinson), and for some remains controversial. It includes a generic description of the role of credit creation in banking not attempted by his contemporary critics. Schumpeter's approach includes a customary means by which a creditor bank may seek to overcome transaction obstacles and thus lessen the costs resulting from asymmetric information, which otherwise would often force the adoption of incomplete lending contracts. Modern structured finance techniques such as nonrecourse project finance or securitization are intended to limit to the greatest possible extent the incompleteness of financing contracts. In each case, contractual structuring results in the debtor having no surplus value, so as to become theoretically constrained from engaging in activity outside the financed enterprise.

By contrast, lending conducted under typical incomplete contracts involves credit risks subject to unquantifiable Knightian uncertainty, since lenders can only be partially informed as to the scope of activities of companies to which they lend. Even though lenders may hope to mitigate the effects of incomplete contracts by incorporating covenants and assignments of actual or potential revenue into contracts, the result will inevitably be subject to general practice and comparative strengths in negotiation. Even if a lender has full knowledge of a debtor enterprise, the volition of the debtor may lead to default, which on occasion may be economically rational. ${ }^{40}$ Other mechanisms to encourage contract compliance (given that few non-fraudulent debtors in advanced economies now face the threat of prison) include socioeconomic forces of the kind traditionally associated with distinct lending markets, for example, in the financing of the trade in diamonds or ship purchase. By this view, the taking of collateral is thus not related to information discontinuities but represents a sanction to encourage contract compliance by the debtor. In terms of institutional analysis it will typically constitute a distortion,

38. Rainer Haselmann, Katharina Pistor \& Vikrant Vig, How Law Affects Lending (Colum. L. Econ. Working Paper No. 285, 2005). By contrast, this may not have been the case in the British industrial revolution, when the existence of reliable non-possessory land mortgages failed to induce banks to lend in a major way to industrial capitalists, allowing historians to discount the importance of finance in development; see MAURICE DOBB, STUdies IN THE DEVELOPMENT OF CAPITALISM (1947); MICHAEL FLINN, ORIGINS OF THE INDUSTRIAL REVOLUTION (1966) 52-53. A similar pattern of bank passivity is observed in the United States at the turn of the twentieth century; see Naomi R, Lamoreaux, Margaret Levenstein \& Kenneth L. Sokoloff, Financing Invention during the Second Industrial Revolution: Cleveland Ohio 1870-1920, $27-30$ (Nat'l Bureau of Econ. Res. Working Paper No. 10923, 2004). Yet only after 1850 did a reliable form of non-possessory chattel mortgage emerge in Britain, and it was arguably not fully trusted by lenders until the early twentieth century. ROY GOODE, COMMERCIAL LAW 586 (3d ed. 2004). Neal observes that England's preceding seventeenth to eighteenth century "financial revolution" has long been underestimated in its effect on later commercial development, see Larry Neal, The Finance of Business during the Industrial Revolution, in 1 THE ECONOMIC HISTORY OF BRITAIN SINCE 1700, 151 (Roderick Floud \& Deirdre McCloskey eds.(1994). Hartwell similarly acknowledges a lack of attention to private finance in growth studies, describing the service sector as the "neglected variable"; see RONALD MAX HARTWELL, THE INDUSTRIAL REVOLUTION AND ECONOMIC GROWTH (1971).

39. JOSEPH SCHUMPETER, BuSiNESS CYCles: A THEORETICAL, HistoriCAL, AND STATISTICAL ANALYSIS OF THE CAPITALIST PROCESS (1939).

40. For example, in the case of home mortgage loans where the value of collateral falls below the amounts outstanding, given certain limits to creditor rights in bankruptcy. 
enabling credit substitution to become the means by which a bank lender avoids the moral hazard associated with asymmetric information.

At the same time, contrary to the findings of certain studies of domestic U.S. practice-except in cases where recourse to the principal debtor is non-existent or limited-taking security is not generally a device to signal credit quality but the converse, ${ }^{41}$ as with conventional non-recourse project finance. Rather, it serves three main purposes for the principals involved or prospectively engaged in financial bargaining, shown in Figure 1.

\section{FIgURE 1: PRINCIPAL FUnCTIONS OF COLLATERAL}

\section{Transformative}

(A) Mitigation or substitution in credit risk for a potential financier.

(B) Change in capital asset use to make financing available.

Informative

(C) Signal credit risk strengths or borrower status.

(D) Signal risk or bargaining weaknesses.

(E) Facilitate credit substitution.

\section{Providing incentives}

(F) Effect on costs and information for credit creation.

(G) Provide financiers with known credit risks.

(H) Encourage contractual compliance by collateral providers.

Adequate institutional infrastructure enable banks to extend the duration of their loans and reduce regulatory capital costs by providing greater confidence as to the credit risk associated with likelihood of repayment. In this regard, two aspects of lending infrastructure are especially important for risk management: an effective system for taking security, and sufficient sources of information through accounting standards, audit practice, credit rating methodology and oversight, and acceptable credit information systems. In addition, banks need systems to manage risks appropriately, these typically being required by capital adequacy and other prudential regulatory requirements.

41. This and other motivations for borrowers to grant security have been questioned notably by Schwartz, who (assuming with Modigliani and Miller that the value of an enterprise is unrelated to the composition of its capital) asks whether security represents an efficient practice, given its effect on other potential creditors and the interplay of priority of claims with U.S. precepts of bankruptcy. See Alan Schwartz, Security Interests and Bankruptcy Priorities: A Review of Current Theories, 10 J. LEGAL STUD. 1, 1 (1981) [hereinafter Schwartz, Security Interests]; Alan Schwartz, The Continuing Puzzle of Secured Debt, 37 VAND. L.R. 5, 1051 (1984) [hereinafter Schwartz, Puzzle of Secured Debt]; Franco Modigliani \& Merton Miller, The Cost of Capital, Corporation Finance and the Theory of Investment, 48 AM. ECON. REV. 261 (1958). A more recent study suggests that collateral provides incentives for lenders to monitor loan performance and is correlated with generally poor business conditions or the debtor's financial distress. See Raghuram Rajan \& Andrew Winton, Covenants and Collateral as Incentives to Monitor, 50 J. FIN. 1113 (1995). 
As an institution of risk management, an effective system to create security allows lenders to obtain collateral to reduce unwanted credit risk and have confidence that such collateral may be realized where necessary to permit the full or partial repayment of a loan. Effective security creation and registration thus provides two advantages for lenders. First, it allows the limiting of monitoring costs by means of partial or complete credit risk substitution, providing that no failure to monitor collateral results in the erosion of security protection. Second, it increases simplicity in lending decision-making, thereby increasing the probability that such decisions will be made. ${ }^{42}$

If property rights are to create capital, they must be applied to procure funding so that the taking of security is the lender's simplest form of risk mitigation. Loans are disbursed provided the lender is given a contingent claim to property of a proportionately equivalent or greater value. If the debt is not satisfied, the lender retains the property and need take little or no account of the credit risk of the borrower. In this simple case, the availability of collateral induces marginal lending. However, to prompt this simple transaction, the lender must be confident of retaining rights to the property given contractual non-payment by the debtor. Thus, the borrower must have valid initial title to the property, and the law must provide for certain and effective transfer of ownership in the event of the security being enforced. Finally, the lender will need a means to appraise supporting collateral. This has often been a problematic feature of all economies, whether developed, emerging, transition, or developing, and usually in the context of loans secured by real property.

Complex collateral-based lending involves sophisticated distinctions between property rights and the certainty of contractual enforcement, derived from the prevailing legal and institutional framework. For example, in the simple transaction of the preceding paragraph, a borrower provided physical, recognizable collateral to secure its indebtedness, as in the common South Asian example of personal loans secured by quantities of gold or silver. This is collateral deployed in its most simple form. For reasons presented in the preceding paragraphs, the use of collateral in secured transactions can become more complex only to the extent that it is supported by an adequate legal and institutional framework. If a borrower must deliver physical collateral to a lender then poorly capitalized enterprises will lack access to most secured lending, and excessive transaction costs render the exercise sub-optimal.

With institutional support for more advanced practices, a borrower may be allowed physical possession of collateral pre-dating the creation of a new loan, thus keeping day-to-day control of the use and enterprise value of existing assets, whether land, buildings, plant, or machinery. At a still more sophisticated legal level, a loan might be used to purchase real property or productive assets, secured by those newly-acquired assets, with the borrower retaining their full use in ways that may be expected to assist in the servicing of the loan. While the mechanics of such transactions are simple to describe, this type of purchase money security is not universally supported by security or bankruptcy law. Whether national law allows or

42. The contrary argument is that over-reliance on collateral in lending to commercial enterprises represents an inefficient solution and raises a moral hazard, in each case by disassociating the creditor from a true interest in the borrower's commercial prospects. Even if this is not the case, in certain common law jurisdictions where banks may be encouraged to seek security interests in order to gain a degree of contractual influence over the debtor. 
limits such arrangements reflects an underlying view of the economic welfare associated with security and collateral. This is seen in the competing views of a commercial enterprise as being either revenue generating or a custodian of assets, and may result in the legal treatment of the purchase of money security as unfairly benefiting individual creditors at the expense of others. ${ }^{43}$

In each case, transaction complexity requires greater legal sophistication, and deploying moveable property as collateral typically requires a more complex legal framework than real property. Furthermore, while real or movable physical collateral is associated with the largest share of secured lending in most emerging and developed economies, intangible property may also represent potential collateral, including intellectual property or trade receivables. The rights of a secured creditor could thus extend to defined classes of assets such as inventory or receivables, to a company's entire asset base if it becomes subject to whole business securitization, or where debts are secured by floating charges as found in English law and certain other common law jurisdictions. They might also extend to the right to receive revenues rather than actual receipt of revenues, providing in each case that the institutional system is sufficiently supportive.

Simple financial markets are greatly enhanced when the availability of collateral increases, even though there may be diminishing returns in the welfare created by collateral-based lending. As a minimum, functional markets require that real property used as security be left in the possession of the borrower, and that security over movable assets does not hinder their normal commercial use. ${ }^{44}$ Developed financial markets typically operate with a wide range of feasible collateral assets, and sophisticated financial markets similarly require commensurate techniques for taking security, for example, in using future receipts and providing for securitization. Nonetheless, questions and anomalies exist even in advanced financial markets. De Soto asserts that property must be allowed in use as collateral in order to encourage economic development, but then fails to distinguish between the legal and institutional issues concerning property, which he addresses in a "capitalization process," and in the use of property as collateral, except in relation to the recording or registration of property rights. In reality, capital is created or released only given both aspects of the framework supporting the use of property and property rights as collateral for secured transactions. To refine de Soto's analysis, property rights must exist and property must also be usable in support of funding for a financial system to develop comprehensively beyond a basic level. ${ }^{45}$

Despite the importance of collateral and secured transactions, this is an area of law involving highly varied legal systems, which in developed jurisdictions is also highly technical. Perhaps as a result, secured transactions tend to receive analytical attention at relatively advanced levels and involve those emerging economies that are already well-progressed in systems supporting basic secured transactions. Once

43. An alternative approach distinguishes between the common law view of the firm as a nexus of contractual bargains, following Ronald H. Coase, The Nature of the Firm, 4 ECONOMICA 386 (1937), and the more civilian view of the firm as a commercial hub of rights and obligations.

44. Which might be the case, for example, under the traditional English common law mortgage or civil law possessory pledge.

45. Note that in certain jurisdictions in the study core group, sophisticated financial transactions and state funding mechanisms exist alongside relatively primitive consumer banking or low-scale credit creation. 
such transactions are supported by a legal and institutional system, there is considerable development potential in enhancing similar support for more advanced secured transactions. Furthermore, sophisticated transactions may provide an interim financing solution for states with incomplete or emerging legal systems.

\section{A. Real Property}

Recent research supports the view that systems of finance based upon property are highly relevant to financial and economic development. ${ }^{46}$ Byamugisha's 1999 World Bank study develops a theoretical framework to guide the empirical analysis of the effects of property finance on an entire economy, ${ }^{47}$ arguing that the conceptual framework linking real estate finance to financial development and economic growth has five main features. First, land tenure security and investment incentives; second, land title, collateral, and credit; third, land liquidity, deposit mobilization, and investment; fourth, land markets, transactions, and efficiency; and last, labor mobility and efficiency. All must be effective to facilitate real estate-based finance, and each demands the existence of appropriate legal infrastructure.

Given the significance of real estate finance for economic development, an ensuing question focuses on markets in which the secondary refinancing of mortgage lending is prominent. For example, a 1997 World Bank study analyzed factors hindering the development of home loan markets in the transition economies of Central and Eastern Europe and proposed a strategy to expedite their development. $^{48}$ The analysis shows that banks in transition economies may be reluctant to make mortgage loans for house purchase because of the scale of risks they perceive in such lending; that is, the extent of credit, interest rate basis, and liquidity risks. It suggests that a secondary mortgage market is likely to assist in solving these problems by allowing banks to manage their loan books to meet preferences over risk concentration and duration, assuming that the initial primary provision of loans meets certain institutional standards.

A third World Bank study argues that successful land and real estate reforms must be "comprehensive in design, even if implementation is phased in over time." It contends that such reforms include three elements: first, institutional reforms that better define property rights, reduce information asymmetries and improve contract performance (termed Property Rights, Information, Contracting and Enforcement);

46. In addition to de Soto's suggestion, supra note 31, that legal reform in developing economies can energize idle capital, North \& Thomas, supra note 12, argue that efficient economic organization is the key to growth; Nathan Rosenberg \& L. E. Birdzell, Jr., How THE WEST GREw RICH: THE ECONOMIC TRANSFORMATION OF THE WESTERN WORLD (1986), argue that Western economic development hinged on factors promoting experimentation; Goldsmith, supra note 25 , provides empirical evidence that the growth of democratic freedoms and property rights in poor countries may lead to increased local prosperity; Johan Torstensson, Property Rights and Economic Growth: An Empirical Study, 47 KYKLOS 231 (1994), applies empirical analyses of property rights and economic growth to substantiate the findings of both Rosenberg \& Birdzell and North \& Thomas.

47. Frank Byamugisha, The Effects of Land Registration on Financial Development and Economic Growth: A Theoretical and Conceptual Framework (World Bank Pol'y Res. Working Paper No. 2240, 1999).

48. Dwight M. Jaffe \& Bertrand Renaud, Strategies to Develop Mortgage Markets in Transition Economies (World Bank Pol'y Res. Working Paper No. 1697, 1996).

49. Ahmed Galal \& Omar Razzaz, Reforming Land and Real Estate Markets 31 (World Bank Policy Research Working Paper No. 2616, 2001). 
second, capital market reforms making mortgage finance available at reasonable costs, especially for the poor (Finance and Risk Management); and third, market reforms that reduce or eliminate distortions in the price of goods and services, the production of which is enabled by land and real estate assets (Market Regulation and Fiscal Policy). Their conclusions tie effective mortgage markets to the broader concept of using real estate finance to encourage all aspects of financial and economic development.

Jaffee and Renaud suggest that secondary mortgage markets confer two main benefits: allowing lenders to shed risks associated with holding mortgages, and creating common standards for credit evaluation and collateral procedures that lead to greater efficiency in new mortgage lending. They suggest that governments adopt catalytic policies in developing secondary mortgage market systems and institutions. This follows the experience of the U.S. and certain other developed countries, and has been adopted by several of the jurisdictions considered in this article.

\section{B. International Standards for Movables}

Wide disparities exist in secured transactions law in developed economies, and are often central in distinctions between common and civil law traditions. ${ }^{50}$ As a result of those disparities, there exist no internationally agreed standards or principles governing secured transactions. ${ }^{51}$ Creating effective provisions for secured transactions demands a mastery of many aspects of an entire legal system, including laws of property, obligations, insolvency, and civil procedure, and of administrative practices and procedures such as registration and enforcement. Nonetheless, research shows that the sound development of legal infrastructure underlies functioning collateral-based credit provision and that inadequacies in such infrastructures hinder financial and economic development. ${ }^{52}$

Recent guidance from the Bank for International Settlements (BIS) describes the features of a generic collateral and credit law, ${ }^{53}$ which include two main elements. First are credit laws to govern creditor-debtor relationships in commercial transactions. These may be established by common law, contract law, civil codes or specific legislation, for example, in usury laws, banking statutes or creditor-debtor statutes. Second, are pledges and collateral laws helping to create and enforce rights in collateral security, preferably through legislation of specific or general application, rather than through contract or common law. Such laws establish priority rankings among secured and unsecured claims in situations of default or insolvency, requiring legislation of a specific or general application.

50. For an excellent discussion, see Frédérique Dahan, Secured Transactions Law in Western Advanced Economies: Exposing Myths, in EUROPEAN BANK FOR RECONSTRUCTION AND DEVELOPMENT, LAW IN TRANSITION 37 (2000), and sources cited therein.

51. See Arjun Goswami \& Hamid Sharif, Preface in Nuria de la Pena, Heywood Fleisig \& Philip Wellons, Secured Transactions Law Reform in Asia: Unleashing the Potential of Collateral, in LAW AND POLICY REForm AT THE ASIAN DeVElopment BANK 2 (2000).

52. See generally de la Pena et al., supra note 51.

53. BANK FOR INT'L SETTLEMENTS COMMITTEE ON PAYMENT AND SETTLEMENT SySTEMS, General GuidanCE for NATIONAL PAyMENT SySTEM DEVElopMENT 65-5 (2006). 
Example of such laws and regulations include the U.S. Uniform Commercial Code (UCC) Article 9; the European Union Directive 2002/47/EC on financial collateral arrangements; the 1997 OHADA Uniform Law on Security Rights; the 1994 European Bank for Reconstruction and Development (EBRD) Model Law on Secured Transactions; the UNCITRAL Legislative Guide on Secured Transactions; the Cape Town Convention on International Interests in Mobile Equipment; and the West African Economic and Monetary Union Regulation 15/2002/CM/UEMOA Regarding Payment Systems in the Member States.

Among multilateral agencies, the EBRD's Model Law is one of the few international standards for secured transactions that has been applied successfully as part of an established process to collateral law reform, drawing also upon the Bank's core principles and glossary. ${ }^{54}$ The Asian Development Bank (ADB) has assisted in creating specific new secured transaction frameworks and the World Bank has addressed some of these issues in relation to insolvency. More directly, the United Nations Commission on International Trade Law (UNCITRAL) is completing a Legislative Guide on Secured Transactions. ${ }^{55}$ Other significant international efforts have been made by the International Institute for the Unification of Private Law (UNIDROIT) ${ }^{56}$ while regional efforts are under way in North America ${ }^{57}$ Asia, ${ }^{58}$ and Europe. In addition, important harmonization efforts were made in respect of U.S. UCC Article 9 and Canada's Personal Property Security Acts, with both frameworks often serving as models in East Asia and elsewhere.

\section{Collateral in East Asia}

A sound framework for secured lending can encourage the provision of credit and assist in the development of domestic financial markets. At the same time, any system that involves the widespread use of collateral assets to support corporate lending may risk fostering a monopolistic banking sector. The use of secured lending as a proxy for informed risk appraisal can become inefficient to the economy as a whole, both by encouraging wasteful credit risk substitution and acting as a force oppressive to non-financial trade creditors. ${ }^{59}$ In East Asia, an over-reliance by lenders on the use of private and corporate real estate as collateral for corporate credit may have contributed to the scale and rapidity of the 1997-98 financial crisis. Following the widespread collapse of asset values, this over-reliance provoked a severe subsequent credit squeeze affecting otherwise "healthy" borrowers, even in national markets that were the least affected by the general loss in confidence. Collateral must be available as security to release the flow of capital but not so unreasonably as to protect the oppressive and inefficient.

54. See John Simpson \& Joachim Menze, Ten Years of Secured Transactions Reform, in EUROPEAN BANK FOR RECONSTRUCTION AND DEVELOPMENT, LAW IN TRANSITION 20 (2000).

55. See UNCITRAL, http://www.uncitral.org (last visited Nov. 24, 2006).

56. See UNIDROIT, Convention on International Factoring, May 28, 1988, available at http:/www.unidroit.org/english/conventions/1988factoring/main.htm (last visited Nov. 24, 2006); UNIDROIT Convention on International Interests in Mobile Equipment (2001), available at http://www.unidroit.org/english/conventions/mobile-equipment/main.htm (last visited Nov. 24, 2006).

57. See American Law Institute, International Secured Transactions Project (1997), available at http://www.ali.org (last visited Nov. 24, 2006).

58. See de la Pena, Fleisig \& Wellons, supra note 51.

59. See also supra notes 41 and 42. 
These concerns prompt a series of questions applicable to any jurisdiction. First, to what extent is commercial secured lending or title finance possible? Second, what legal provisions exist for home mortgages? Third, what provisions are made for the transfer of secured claims? Fourth, what are the principal effects of related legal reforms, for example, in civil jurisdictions that choose to enact wholesale securitization legislation? Fifth, what is the position of secured claims vis-à-vis statutory priority, for example, in government or employee creditor claims? Last, is there simplicity of execution, perfection, notification, registration, and enforcement? Table 2 synthesizes an analysis of these issues in the economies addressed by this study, using a rising 1-5 scale. Scores such as $2 / 3$ represent an intermediate appraisal between two given levels. As with Tables 5, 7, and 8, these "split" scores are intended to reflect degrees of uncertainty as to commercial outcomes.

\section{TABLE 2: LEGAL FRAMEWORK FOR CREDITOR RIGHTS}

\begin{tabular}{lllll}
\hline & $\begin{array}{l}\text { Enforcement } \\
\text { of Unsecured } \\
\text { Rights }\end{array}$ & $\begin{array}{l}\text { Security } \\
\text { Interest } \\
\text { Legislation }\end{array}$ & $\begin{array}{l}\text { Registration } \\
\text { and Disclosure } \\
\text { of Secured } \\
\text { Rights }\end{array}$ & $\begin{array}{l}\text { Enforcement } \\
\text { of Secured } \\
\text { Rights }\end{array}$ \\
\hline Cambodia & 1 & $1^{60}$ & $1^{61}$ & 1 \\
China & 2 & 2 & 2 & 2 \\
Indonesia & 1 & 2 & $1 / 2$ & 1 \\
Malaysia & 5 & 4 & 4 & 5 \\
Philippines & 2 & $2 / 3$ & $2 / 3$ & 2 \\
South Korea & 3 & $1 / 2$ & $1 / 2$ & $2 / 3$ \\
Taiwan & 3 & 4 & 3 & $3 / 4$ \\
Thailand & 2 & $1 / 2$ & 2 & 2 \\
Vietnam & 1 & 1 & 1 & 1 \\
\hline Hong Kong & 5 & 4 & 4 & 5 \\
Singapore & 5 & 4 & 4 & 5 \\
\hline
\end{tabular}

Here, granting and making security effective is treated as a form of property right, regardless of the nature of the legal systems under review. Any appraisal will therefore question how the law links the granting of security to the rights of general creditors in both normal and distressed circumstances. Table 2 thus shows how the system now supports, undermines, or confuses all aspects of secured transactions. No account is taken of informal systems, even if commercially entrenched. ${ }^{62}$ Ideally, the law will allow simple cost-effective creation of security without affecting rights of

60. When enacted, a forthcoming secured transactions law is expected to allow a score of " 4 " in this category.

61. When implemented, new provisions are expected to allow a score of " 4 " in this category.

62. But account is taken of legal provisions peculiar to certain jurisdictions, such as Taiwan's right of dien which is recognized in the Civil Code Art. 911 as a form of leasehold interest in immovable property, or the contractual antichresis permitted under the Philippines Civil Code Art. 2132, but which is increasingly disused as a form of pledge. 
conventional day-to-day collateral usage. It will be public, transparent, function without discrimination, and be enforceable in ways compatible with declared public policy, especially in relation to insolvency, receivership, and rearrangements following corporate distress.

The effectiveness of a national legal and administrative framework permitting the creation of collateral for secured transactions is revealed in several elements, not all of which are consistently present in the review countries. Among the matters to be considered are the ease and cost of creating reliable security interests, the systems for such interests to be disclosed, the costs and risks associated with the enforcement of charges, the relationship of security and collateral with insolvency and receivership practice, and the operation of creditor protection and stays to enforcement. These are contained in Table 2.

Civil and common law traditionally have different approaches to security interests, and the introduction of reform always needs to be sensitive to the existing contractual and legal setting. While the EBRD Model Law on Secured Transactions was intended to be adopted by jurisdictions of all types, it is likely that the presence of relatively well-developed legal systems in the core review group make a single benchmark impractical. Such a device might have value, however, in other developing Asian jurisdictions. ${ }^{63}$ Elsewhere, recent legislative reforms appear to be effective in supporting transaction creation, but have yet to be tested in cases involving economic stress, in particular a downward phase in the credit risk cycle or weakening. This applies to Indonesia, South Korea, and Thailand, for example, as well as to Cambodia's pending Secured Transactions Law and the registry that will support its implementation. In each case, a further concern for the integrity of new laws in relation to existing and succeeding legislation may arise, given that measures are often introduced in discrete steps despite leading to a complex commercial whole. In China, for example, legislation introduced since 2003 has necessitated the reconsideration of statutes that were created in recent but earlier days of reform. Likewise, implementation of China's 2007 Property Law is likely to have significant impact, though the exact scope is as yet unclear.

In a related area of law, securitization legislation or decrees have been adopted in recent years and remain largely untested in Indonesia and the Philippines. ${ }^{64}$ Those introduced in South Korea, Taiwan, and Thailand appear to be transactionally sound but have not yet been made subject to credit or valuation stress of the kind indicated in the preceding paragraph.

\section{Overview}

Asia's legal provisions for secured credit transactions regimes at the onset of the 1997-98 financial crisis were at least as outdated and inefficient as its insolvency laws. Yet less effort has since been made to reform those laws. Immediately after the crisis, most attention was directed to reforming corporate reorganization procedures and other features of insolvency law, even though such laws cannot work

63. Vietnam, for example, introduced a general bankruptcy law in 1993 (and a new bankruptcy law in 2004) and commercial and property laws in 1991.

64. A recent unreported decision of the Indonesian Supreme Court may affect the use of a special purpose vehicle to facilitate foreign currency borrowing by Indonesian entities. See Kate Linebaugh, How Indonesia's Bond Market Stayed Hot Despite Court Ruling, WALL ST. J. AsIA (Nov. 10, 2006) at A22. 
efficiently when secured creditors find it difficult or impossible to enforce their rights in bankruptcy. Such delays were common in Asia prior to the financial crisis. ${ }^{65}$ Similarly, credit creation is adversely affected when either valid collateral must be held in possession by a secured creditor or limits exist to the permissible categories of assets that may be used as collateral. As will be seen in the country-specific discussion below, these problems were also endemic prior to the crisis, ${ }^{66}$ but its impact finally drew attention to the need for coordinated legal reform as well as the creation of modern provisions for secured transactions. Thailand is an example of how this acceptance has been made, as legislation was under preparation immediately prior to the suspension of the legislature in September 2006.

\section{Real Property}

In each jurisdiction within this study, the legal system provides for real property to be offered and taken as collateral. However, there is considerable divergence as how best to resolve a variety of issues, including the following: the ease and efficiency with which mortgages, charges or liens may be created; the requirements for registration and its usefulness to third parties; whether a mortgagor retains title to collateral while the extension of credit that the charge purports to secure remains outstanding; and how secured creditors may enforce their collateral rights. Differences also exist in some cases in the treatment of collateral arising from varying statutory provisions for real property ownership by domestic and foreign interests.

Table 3 does not address the distribution of property rights, which is a focus of de Soto's work that merits further attention in the context of the relationship between state governance and property rights, and economic outcomes.

\section{TABle 3: Treatment of REAl Property}

\begin{tabular}{ll}
\hline Cambodia & $\begin{array}{l}\text { Real property may be mortgaged, but enforcement can be } \\
\text { extremely problematic. Registration is efficient and effective. A } \\
\text { foreign creditor may take a mortgage over land but not become } \\
\text { the owner of land. }\end{array}$ \\
\hline China $^{67}$ & $\begin{array}{l}\text { Land may not be mortgaged, but mortgages over land-use rights } \\
\text { are permitted. Registration is necessary to protect secured }\end{array}$ \\
& creditor rights. The enforcement of a mortgage can require \\
& litigation in cases in which the mortgagee and mortgagor cannot \\
& reach agreement as to how the mortgagee claim may be \\
& satisfied. Transactions involving mortgages to be held by \\
& foreign entities are subject to prior approval and registration \\
& with the State Administration of Foreign Exchange (SAFE). \\
\hline
\end{tabular}

65. See ADB Office of the General Counsel, Insolvency Law Reforms in the Asian and Pacific Region, Report of the Office of the General Counsel on TA 5795-Reg: Insolvency Law Reforms, Law and Policy Reform at the ADB 10-11, 70-75 (2000) [hereinafter Report on Insolvency Law Reforms].

66. See Lampros Vassiliou, The Restructuring Revolution in the Asia-Pacific Region, in THE AsIAPACIFIC RESTRUCTURING AND INSOLVENCY GUIDE 2006 18, 21 (2006).

67. After extensive discussions and the withdrawal of an earlier draft law in 2006 , a new property 


\begin{tabular}{ll}
\hline Indonesia & Security interests may be taken in land, but it often proves \\
& difficult for creditors to enforce a security interest. The process \\
is inefficient; enforcement can take many years. Auction fees & and taxes are high and, in practice, recourse to the courts is \\
& almost always necessary. ${ }^{68}$ Official registers are maintained \\
& manually, which causes difficulties for potential lenders wishing \\
& to search for title or prior claims. ${ }^{69}$ Security rights may be \\
& impaired by the creation of a parent company guaranty in \\
& respect of like debt. \\
Real property may be mortgaged (under provisions of the Civil \\
Code). While both registration and notarization are necessary \\
for creditor protection, the requirements are set out in a mix of \\
statute and presidential decree. Ownership is retained by the \\
mortgagor while a charge is outstanding. Delays in foreclosure \\
can occur because the secured party must use the courts in the \\
absence of any contractual agreement for extrajudicial \\
foreclosure. Contractual antichresis was a common form of \\
commercial pledge, but it is becoming increasingly less used. \\
Unless stated by agreement, mortgages over land will embrace \\
subsequent buildings or improvements to the land, and may \\
gain inadvertent priority over other subsequent charges. \\
Foreign creditors may become mortgagees of land but not \\
buildings, and may subsequently not take possession of land. \\
\hline
\end{tabular}

rights law was approved by the 10th National People's Congress in March 2007, to take effect on October 1, 2007. See Property Rights Law of the People's Republic of China 2007. This covers both real property and movable assets, and for the first time establishes rights in respect of both state and non-state interests. The law makes most real property ownership rights contingent upon registration. See id. Art. 9-22. Art. 170-240 establish conditions for the granting of security interests by a property owner, including the right to mortgage real property and specified movable assets, and the right to pledge other assets, including certain defined intangibles. The creation of registry facilities throughout China will be a considerable administrative burden.

68. EMIR NuRMANSYAH, THEODOOR BAKKER, ClifFord REES \& DAVID ADAMS, Indonesia: ThE ASIA PACIFIC RESTRUCTURING AND INSOLVENCY GUIDE 80 (2006).

69. Id.

70. Ricardo Ongkiko, Carina laforteza, Carlos franciso \& Cosette Canilao, PhilipPINes: THE ASIA PACIFIC RESTRUCTURING AND INSOlVENCY GUIDE 135 (2006), noting that mortgage contracts now usually provide for extra-judicial foreclosure to address this problem. 


\begin{tabular}{|c|c|}
\hline South Korea & $\begin{array}{l}\text { Most real estate rights must be registered. However, there are } \\
\text { important exceptions from this rule (e.g., property acquired } \\
\text { through inheritance or pursuant to a judgment auction). }\end{array}$ \\
\hline Taiwan & $\begin{array}{l}\text { The Civil Code allows mortgages to be created over defined } \\
\text { classes of real property, and for possessory security or } \\
\text { attachments. In addition, the right of "dien" is allowed as a } \\
\text { form of possessory pledge similar to a leasehold interest, and } \\
\text { may be created effectively over assets not specified in law. } \\
\text { Registration in all cases is mandatory and efficient, without } \\
\text { which the charge will be void. There is some uncertainty as to } \\
\text { whether notice or consent is required of a secured creditor for } \\
\text { the creation of a subsequent mortgage. Foreign creditors are } \\
\text { restricted as to the types of real property over which they may } \\
\text { hold security interests. }\end{array}$ \\
\hline Thailand & $\begin{array}{l}\text { Real property may be mortgaged and registration is necessary } \\
\text { to protect the secured creditor's rights, but foreclosure cannot } \\
\text { occur unless loan interest or charges have been outstanding for } \\
\text { five years, contributing to an inefficient enforcement process } \\
\text { that can extend over many years. Separate charges are } \\
\text { necessary in respect of plant or equipment contained in a } \\
\text { mortgaged property, and may be subject to official inspection. }\end{array}$ \\
\hline Vietnam & $\begin{array}{l}\text { The } 1992 \text { constitution adopted the general recognition of } \\
\text { private property rights but land ownership continues to be } \\
\text { vested solely in the state. Nonetheless, rights of land use are } \\
\text { clear and may be mortgaged under the Land Law of } 1993 \text {. }\end{array}$ \\
\hline $\begin{array}{l}\text { Hong Kong, } \\
\text { Malaysia, } \\
\text { Singapore }\end{array}$ & $\begin{array}{l}\text { All allow for a charge to be taken over land, which must be } \\
\text { registered. }{ }^{2} \text { Hong Kong and Singapore also provide for } \\
\text { mortgages to be taken over land, but in Hong Kong (since 1984) } \\
\text { the mortgage may be created only by a legal charge. The } \\
\text { Malaysian courts will generally recognize a charge that is } \\
\text { executed but not yet registered. All three jurisdictions allow for } \\
\text { the appointment of a receiver to protect the creditor's interest } \\
\text { and in all three jurisdictions there is a high level of predictability } \\
\text { and efficiency as to the creditor's ability to enforce its rights. } \\
\text { Hong Kong land ownership is (with a single exception) held by } \\
\text { the territory's government but this does not materially affect } \\
\text { rights of use or the creation of security. }\end{array}$ \\
\hline
\end{tabular}

71. It was until recently customary for lenders to require registration of a "comprehensive mortgage" over an undefined amount prior to approving a loan (compared to the widespread practice elsewhere making disbursal subject to security conditions) but the practice was held invalid by the courts as being contrary to the specificity required of charges by the Civil Code. Reform has not yet been completed.

72. Laws governing land registration differ between Peninsular and East Malaysia, the latter excluding Labuan, which became a federal territory in 1990 upon being designated an offshore financial center. The taking of land and movable assets owned by Labuan companies as collateral is governed largely by the Offshore Companies Act 1990. 


\section{Movables and Unsecured Property}

The treatment of secured rights over movable property is still more varied throughout the study group. Although none of the jurisdictions within this study has adopted a U.S. Article 9-style regime, the English origin systems of Hong Kong, Malaysia and Singapore work relatively well. However, Table 4 shows that delays and inefficiencies in the enforcement of secured rights are common. Similarly, limits to the movable assets that may be used as collateral is problematic or constraining in most jurisdictions. These include bars to taking security interests in chattel paper or accounts receivable, and more broadly a lack of provisions for charges over future property or the use of security to collateralize future loans. 


\section{TABLE 4: TREATMENT OF MOVABLES}

\begin{tabular}{|c|c|}
\hline Cambodia & $\begin{array}{l}\text { A new Secured Transactions Law is expected to be enacted in } \\
\text { the foreseeable future, providing a modern legal framework for } \\
\text { security, including support through an electronic registration } \\
\text { system. However, enforcement is likely to remain problematic, } \\
\text { and the commercial effectiveness of the law may be colored by } \\
\text { other current omissions in law. }\end{array}$ \\
\hline China $^{73}$ & $\begin{array}{l}\text { Mortgages may be taken over existing tangible movable } \\
\text { property, but not over future property. Secured creditors must } \\
\text { register their claims to protect all such non-possessory rights. } \\
\text { They may also protect themselves through possession in the } \\
\text { form of a pledge. As with real property, foreign entities seeking } \\
\text { security over movable property must comply with SAFE } \\
\text { approval and registration procedures. The treatment of security } \\
\text { interests in intangible assets such as bank accounts or } \\
\text { receivables is less straightforward. Regulations have been } \\
\text { issued allowing mortgages over such assets, but the } \\
\text { effectiveness of these new forms of collateral is largely untested. } \\
\text { Enforcement of unsecured claims can sometimes run into } \\
\text { resistance at a local level; there have been reported instances in } \\
\text { which banks and their clients have colluded to hide assets from } \\
\text { the court. }\end{array}$ \\
\hline Indonesia & $\begin{array}{l}\text { Under the Fiduciary Security Law, a debtor may transfer title in } \\
\text { goods to a creditor and retain possession of the goods in the } \\
\text { absence of any default. Pledges are also permitted. A fiduciary } \\
\text { assignment may be taken for security purposes over intangible } \\
\text { property and receivables. }{ }^{74} \text { As with real property, enforcement } \\
\text { over movable property requires recourse to the courts, and both } \\
\text { auction fees and taxes are punitive. }{ }^{75} \text { In essence, secured } \\
\text { creditors foreclosing on collateral are forced to resort to } \\
\text { substantially the same court proceedings as unsecured } \\
\text { creditors. }\end{array}$ \\
\hline Philippines & $\begin{array}{l}\text { Chattel mortgages and pledges are permitted over movable } \\
\text { property. Chattel mortgages must be recorded. Philippine law } \\
\text { does not recognize chattel mortgages over future property; but } \\
\text { the courts have created exceptions for interests in inventories of } \\
\text { raw materials, goods in process, and finished goods. Future } \\
\text { obligations cannot be secured by chattel mortgages. }\end{array}$ \\
\hline
\end{tabular}

73. The treatment of movables will be clarified by the introduction of the new Property Rights Law of the People's Republic of China 2007, to come into force in October 2007. See supra note 67, providing at Arts. 179-202 for the creation of mortgages over specified movable assets. Such mortgages will take effect only upon registration.

74. NURMANSYAH ET AL., supra note 68 , at 80.

75. Id.

76. $I d$. 
South Korea Rights in personal property may only be protected by possession. South Korean law does not recognize purchase money security interests or floating liens.

Taiwan Non-possessory charges are possible under the Chattel Secured Transaction Act and by separate laws regarding ships and aircraft. Registration is mandatory in each case in order to protect priority. Enforcement is generally procedural and not subject to judicial uncertainty.

Thailand

Only certain forms of movable property may be mortgaged, including large ships, boats, floating houses, beasts of burden, and classes of machinery. Creditors holding rights of retention are also recognized as secured creditors. Other types of property may be pledged. Enforcement of secured rights requires either a court judgment or a public auction. Enforcement is slow and costly. Fixed and floating charges are not permitted at present, but would be allowed under draft secured transactions law. The enforcement of unsecured debts in Thailand can extend for many years.

Vietnam Private property rights are constitutionally recognized and charges over movables permitted by the civil code. Improvements were made to Vietnam's secured transaction framework in 2005 amendments to the civil code, which took effect in January 2006. Further decrees are expected to assist with the implementation of these changes. A National Registration Agency for Secured Transactions has been established with offices in Hanoi, Ho Chi Minh City, and Danang. However, enforcement of security interests remains difficult. Unless bankruptcy proceedings have been commenced, a court order is not necessary for the enforcement of a secured transaction.

Hong Kong The laws in all three jurisdictions provide a variety of security Malaysia over movable property (both tangible and intangible), including charges, liens, and pledges. Retention of title is also permitted. Singapore Security may be taken over future property. Fixed charges may be taken over tangible assets and floating charges may be taken over classes of variable assets such as inventory or book debts. The taking of fixed charges over book debts by secured creditors is much more difficult.. ${ }^{77}$ These English-origin systems require the registration of many types of charges, including charges over book debts and floating charges over the general undertaking of a company, but statutory rules are less clear and comprehensive than U.S. UCC Article 9. Usual practice in

77. In these three jurisdictions the decision by the U.K. House of Lords limiting the validity of fixed charges over book debts to cases in which the secured creditor exercises sufficient control over the collateral (e.g., through including a provision in the debenture requiring the deposit of proceeds of book debts into a blocked account and in fact operating the account as a blocked account) would be persuasive authority. See Re Spectrum Plus Ltd; National Westminster Bank plc v. Spectrum Plus Ltd. and others [2005] 2 BCLC 269. 
these three jurisdictions is for a debenture to provide a secured financial creditor with contractual remedies upon default, allowing appointment of a receiver or special manager. All have efficient debt collection procedures for unsecured creditors.

\section{Securitization}

Securitized transactions require a permissive framework of existing or dedicated law, acceptance of certain accounting principles, acceptable regulatory assent, and a non-discriminatory taxation background. ${ }^{78}$ They also require accepted commercial precepts that are not matters of legal policy; for example, a lack of contractual restrictions to the transfer of financial claims. Such restrictions are common in all review markets, except in Hong Kong and Singapore.

The details of typical transactions will vary among jurisdictions, but are assumed to entail the irrevocable transfer of assets to an insubstantive special purpose vehicle (SPV) to which the asset seller has no ties of ownership or control. Funding for the asset purchase is provided by the sale of public or private securities to third party investors. The transaction must withstand any legal claim in bankruptcy against the asset seller; its economics must withstand taxes and duties on transfer; in most cases, securities issued by the SPV must provide for the dependable subordination of claims.

In general, the elements of law typically associated with securitized transactions in advanced markets are present in the three common law review jurisdictions, especially those affecting existing or future claims originated by financial intermediaries. However, certain future claims that cannot be specified in ways required by current law may be seen as hazardous source material by investors or third party monoline insurers, such as credit card receivables.

A summary of the provisions for securitized transactions and their effectiveness is given in Table 5. Its assessments of the effectiveness of enabling legal provisions (column 2), the enforcement of foreclosure or repossession of source assets (column 5), and ongoing threats to the integrity of transfer of assets to a SPV (column 6) are in each case based on transactional evidence and appraisals of governing laws. However, it must be noted that in most jurisdictions, transactional integrity has yet to be fully tested through a complete credit cycle. This would apply in relation to new rules such as the creation of real estate investment trusts in common law jurisdictions such as Hong Kong and Singapore. Nevertheless, in each case the probability is small that a completed transaction will be successfully challenged.

While aspects of law may now be clear in some cases, it may be little used, such as law regarding private contracts in the Philippines or Thailand, and is thus yet untested. Further, no significant number of completed securitized transactions has yet to undergo periods of economic stress or be attacked by creditors of the originator. In contrast, since 1998 , South Korean reforms seem to be demonstrably successful.

78. See Douglas Arner, Emerging Market Economies and Government Promotion of Securitization, 12 DUKE J. COMP. \& INT'L L. 505 (2002). 
Malaysian common law supports securitization. Rules setting out general parameters for securitization were first published only in 2001, but sales of whole or partial interests in pools of home mortgages began in the mid-1980s. Shariahcompliant transactions have been few to date and involve intricate structuring at all stages, but are now considered to be generally feasible, at least as single deals.

TABLE 5: PROVISIONS FOR SECURITIZATION

\begin{tabular}{|c|c|c|c|c|c|c|c|}
\hline & \multicolumn{4}{|c|}{$\begin{array}{l}\text { Sale, assignment, or other conveyance of } \\
\text { assets by originators to securitization } \\
\text { vehicles }\end{array}$} & \multicolumn{2}{|c|}{$\begin{array}{l}\text { Creation, } \\
\text { maintenance, } \\
\text { and operation of } \\
\text { SPV }\end{array}$} & \multirow[b]{2}{*}{ 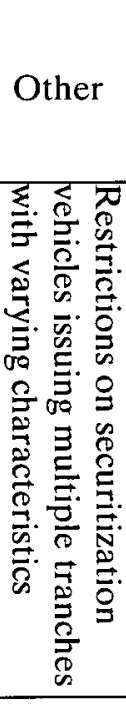 } \\
\hline & 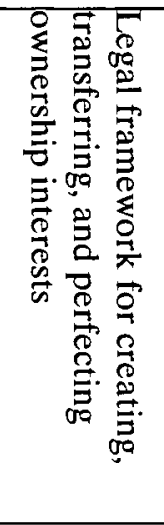 & 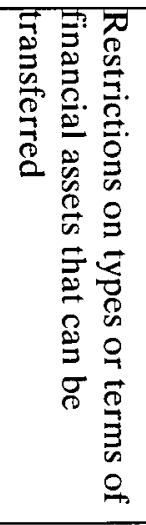 & 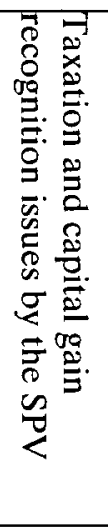 & 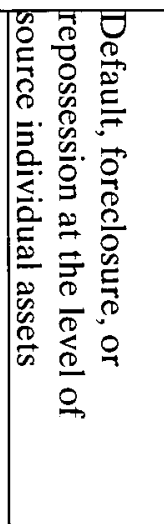 & 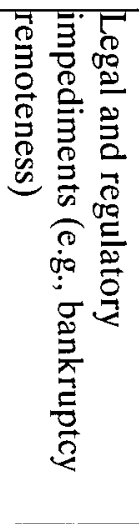 & 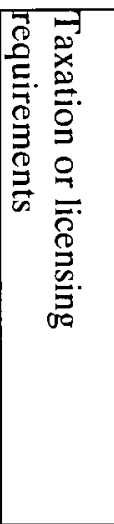 & \\
\hline Cambodia & NA & NA & NA & NA & NA & NA & NA \\
\hline China & $1 / 2$ & 1 & 1 & 1 & 1 & 1 & 1 \\
\hline Indonesia & 2 & 2 & 2 & 2 & 1 & 2 & 2 \\
\hline Malaysia & 5 & 4 & 4 & $3 / 4$ & 4 & 4 & 5 \\
\hline Philippines & $2 / 3$ & $2 / 3$ & $1 / 2$ & $2 / 3$ & $2 / 3$ & $1 / 2$ & $2 / 3$ \\
\hline $\begin{array}{l}\text { South } \\
\text { Korea }\end{array}$ & 5 & 4 & $3 / 4$ & 4 & 5 & 5 & 5 \\
\hline Taiwan & $4 / 5$ & 4 & $3 / 4$ & 4 & 4 & $2 / 3$ & 4 \\
\hline Thailand & $3 / 4$ & 3 & $3 / 4$ & $3 / 4$ & $2 / 3$ & $4 / 5$ & $2 / 3$ \\
\hline Vietnam & NA & NA & NA & NA & NA & NA & NA \\
\hline $\begin{array}{l}\text { Hong } \\
\text { Kong }\end{array}$ & 5 & 5 & 4 & 5 & 5 & 5 & 5 \\
\hline Singapore & 5 & 5 & 5 & 4 & 5 & 5 & 5 \\
\hline
\end{tabular}

Since 1998, four of the eight civil law review jurisdictions have introduced, or are planning to introduce, enabling laws that permit the creation of securitized transactions recognizable by international standards. The most notable provisions are shown in Table 6. In particular, these allow for the creation of SPVs, which would not otherwise be permitted by the general provisions of national civil codes. ${ }^{79}$

79. A recent unreported decision of the Indonesian Supreme Court has created transaction uncertainty in the context of foreign borrowing by affirming the contiguous treatment of a company 
Indonesia permits certain transactions under authority granted to the principal securities regulator, Bapepam. Several Indonesian securitized transactions were completed before 1997 but post-crisis deals are virtually non-existent because counterparties may have been more willing to enter deals in a time of moderate confidence than thereafter. Since 2000 , there has been some doubt that regulatory decrees, upon which any new transaction will depend, may subsist during its lifetime. Finally, certain jurisdictions are affected by related issues of law, tax, or market rules, rather than pure securitization provisions. This increases contractual uncertainty, and applies, for example, in the Philippines and for domestic transactions in Taiwan.

\section{TABLE 6: STATUS OF ENABLING LEGISLATION FOR SECURITIZATION ${ }^{80}$}

\begin{tabular}{|c|c|}
\hline & Years of Enactment or Proclamation \\
\hline Cambodia & None \\
\hline \multirow[t]{2}{*}{ China } & $\begin{array}{l}\text { Major bank and possibly other sector securitization legislation } \\
\text { forthcoming 2007-08 }\end{array}$ \\
\hline & $\begin{array}{l}\text { Trial deals permitted by banking and securities regulators in } \\
2006-07\end{array}$ \\
\hline \multirow[t]{2}{*}{ Indonesia } & Pre-1997 Securitization Decrees \\
\hline & 2002-03 Securities Regulator Guidelines \\
\hline \multirow[t]{3}{*}{ Philippines } & 2003 Special Purpose Vehicle Act \\
\hline & 2004 Securitization Act (largely untested) \\
\hline & $\begin{array}{l}\text { Implementing Rules and Regulations (2005) over credit rating } \\
\text { requirements and the use of SPVs. }\end{array}$ \\
\hline \multirow[t]{3}{*}{ South Korea } & 1998 Asset-backed Securities Law \\
\hline & 1999 Mortgage-backed Securities Law \\
\hline & 2003 Korea Housing Finance Corporation law \\
\hline \multirow[t]{2}{*}{ Taiwan } & 2002 Financial Asset Securitization Act \\
\hline & 2003 Real Estate Securitization Act \\
\hline \multirow[t]{3}{*}{ Thailand } & 1997 Securitization Decree \\
\hline & 2003 Asset-backed Securitization Act \\
\hline & 2004 Special Purpose Vehicle Act \\
\hline Vietnam & None \\
\hline
\end{tabular}

guarantor and its subsidiary SPV and voiding a financing contract to which the two entities purported to be separate parties. This may increase the legal risks of securitized transactions. See also supra note 64.

80. A model for other Asian civil law jurisdictions may have been legislation enabling securitization in Japan, including notably its 1998 Perfection Law, 1998/2000 Asset Liquidation Law, and 2004 Trust Business Law (Amendment). 


\section{CREDITOR RIGHTS AND INSOLVENCY}

At the formative stage of economic development, the risk and incidence of defaults by debtors often prevent the efficient deployment of funds for investment. A proper framework of law that provides both for company incorporation and the orderly resolution of proceedings for recovery and insolvency is therefore a crucial foundation of development.

\section{A. Insolvency}

A functioning legal framework for insolvency management is essential in the operation of any modern market-based economy. No commercial sector can function effectively without mechanisms to recognize and govern the exit of insolvent participants. Furthermore, the financial sector will limit credit creation for many companies and individuals if lenders are uncertain that their status as secured creditors will prevail upon the liquidation of their debtors, or that a reliable means will be available for the enforcement of properly-constituted security. The general objectives of a system of corporate insolvency have been described as the reduction of uncertainty, promotion of efficiency, and fair and equitable treatment for all participants. ${ }^{81}$ A functioning insolvency regime can thus help reduce and simplify the risks associated with lending and the potential cost of debt service; if this is the case, long-run credit availability and capital investment will increase. ${ }^{82}$

Functioning insolvency procedures are thus central to the legal and institutional environment for sound finance in any market-based economy, regardless of whether public policy requires the law to favor debtors or creditors. A well-administered insolvency system may be valuable in promoting market discipline. Effective insolvency laws provide the means for the identification of non-competitive participants and, in some cases, for their controlled exit. It thus provides an effective penalty for the least competitive as well as a potential solution to the ensuing reallocation of resources. While this view stresses the retroactive character of insolvency law, it also has a considerable preventive element by creating incentives for the uncompetitive to improve performance and to avoid the sanction of administration by a third party on its creditor's behalf.

A number of international organizations and associations have assisted the development of standards for modern insolvency law and related systems. Many of these activities have focused in particular on norms and standards for cross-border insolvency cases, such as the UNCITRAL Model Law on Cross-Border Insolvency and the EU Insolvency Regulation of $2000 .^{83}$ A working group chaired by the legal department of the IMF presented a document containing detailed principles for the development of workable, modern insolvency legislation. ${ }^{84}$ While there is no

81. See Report of the G-10, Report of the Contact Group on the Legal and Institutional Underpinnings of the International Financial System (Sep. 2002), available at http://www.bis.org/dcms/fd.jsp?p=1\&uri=/publ/gten06.htm (last visited Nov. 24, 2006).

82. IMF Legal Department, Orderly \& Effective Insolvency Procedures: Key Issues (1999), available at http://www.imf.org/external/pubs/ft/fandd/2000/03/hagan.htm (last visited Nov. 24, 2006). Note that this argument is silent as to the quality of investments so financed.

83. UNCITRAL MODEL LAW ON CROSS BORDER INSOLVENCY WITH GUIDE TO ENACTMENT (1997); Council Regulation 1346/2000 O.J. (L 160).

84. IMF Legal Department, supra note 82. 
internationally agreed key standard in the area of insolvency, the World Bank is coordinating efforts to develop such a benchmark and is working with UNCITRAL to develop a suitable framework for its implementation.

The World Bank first issued its Principles and Guidelines for Effective Insolvency and Creditor Rights Systems in April $2001^{85}$ and a revised version under development will take into account feedback from insolvency assessments conducted under the IMF-World Bank Reports on Observance of Standards and Codes (ROSC) initiative. ${ }^{86}$ The Bank is also preparing a technical report containing detailed implementation guidelines to support the principles. UNCITRAL released a Legislative Guide on Insolvency Law in 2005, a combination of model provisions, recommendations, and explanatory notes that builds upon the work of other international organizations, including the World Bank, IMF, and ADB. ${ }^{87}$

The World Bank identifies nine objectives for effective corporate insolvency: ${ }^{88}$

1) Integrate with broader national legal and commercial systems.

2) Maximize the value of a firm's assets by providing an option to reorganize.

3) Strike a careful balance between liquidation and reorganization.

4) Provide for equitable treatment of similarly situated creditors, including foreign and domestic creditors.

5) Provide for timely, efficient, and impartial resolution of insolvencies.

6) Prevent the premature dismemberment of a debtor's assets by individual creditors seeking quick judgments.

7) Provide a transparent procedure that contains incentives for gathering and dispensing information.

85. World Bank, Principles and Guidelines for Effective Insolvency \& Creditor Rights Systems (Apr. 2001), available

http:/web.worldbank.org/WBSITE/EXTERNAL/TOPICS/LAWANDJUSTICE/GILD/0,CONTENTMD K:20086184 menuPK:146153 pagePK:64065425 piPK:162156 thesitePK:215006,00.html. The Principles (ICRPs) were prepared in collaboration with the AfDB, ADB, EBRD, IADB, IFC, IMF, OECD, UNCITRAL, INSOL International, and International Bar Association.

86. The latest draft dates from 2005. See http://www.worldbank.org/ifa/rose_icr.html (last visited Nov. 24, 2006).

87. See Legislative Guide on Insolvency Law, UNCITRAL, available at http://www.uncitral.org/pdf/english/texts/insolven/05-80722_Ebook.pdf (last visited Nov. 24, 2006).

88. World Bank ICRP 6, 24, (Apr. 2001) (stating that these elements were identified by the G-22). Id. at 24, n.10 (citing G-22 16, 44-45 (1998)). 
8) Recognize existing creditor rights and respect the priority of claims with a predictable and established process.

9) Establish a framework for cross-border insolvencies, with recognition of foreign proceedings.

In supporting these objectives, the thirty-five World Bank insolvency principles cover five main areas: first, a legal framework for creditor rights (principles 1-5); ${ }^{89}$ second, a legal framework for corporate insolvency (principles 6-16); third, corporate rehabilitation (principles 17-24); four, informal workouts and restructuring (principles 25-26); and five, institutional and regulatory frameworks for implementation of the insolvency system (principles 27-35).

The most recent version of the UNCITRAL Guide has two parts. ${ }^{90}$ The first deals with the design of the key objectives and structure of an insolvency law, while Part II includes core insolvency law provisions. Regretfully, until the revised World Bank principles and final UNCITRAL Guide are integrated, approved, and released, it is impossible to identify an international consensus in this area.

\section{B. Interaction between Creditor Rights and Insolvency}

Debtor-creditor laws include systems for collecting debts and insolvency systems for terminating the collection of unpaid debts. Collection systems include: secured transactions, using movable property as collateral; mortgages, using fixed property as collateral; and unsecured lending, a system that employs no property or other rights as collateral. ${ }^{91}$ One view of the interaction between secured lending and insolvency law sees each as addressing distinct problems, with separate solutions. A secured lending system determines how lenders are repaid, whereas an insolvency system establishes the appropriate treatment for defaulting borrowers.

At the same time, there are important points of intersection between secured transactions and insolvency, and the two systems must be integrated. Neither system can substitute for the other. Thus, reforms of debtor-creditor laws must embrace both secured lending and insolvency law, as well as other closely related areas of law. The need for such drafting integration may be more widely realized in East Asia now, as governments contemplate reform, than would have been the case prior to the 1997-98 financial crisis.

Secured transactions have often been seen as important in improving general welfare by helping create and encourage certain benefits for society as a whole. Regardless of the nature of preferred insolvency laws, East Asian national economies are likely to advance by improving their respective laws on secured lending. This relies on the premise that general access to credit, and the specific terms on which it becomes available, will improve in the borrower's favor as the

89. This Section, while at first glance appearing to address collateral and secured transactions, addresses these only in the context of insolvency.

90. UNCITRAL, Draft Legislative Guide on Insolvency Law, A/CN.9/WG.V/WP.70 (Parts I and II) (2003).

91. Banking practice in civil law jurisdictions often treats guarantees as providing security, which is not usual in common law systems, regardless of the effect on credit risk. 
quality of collateral-taking improves. ${ }^{92}$ Effective secured transactions systems that allow for movable property to be used as collateral may allow distressed firms to gain access to credit and so avoid the final resort of insolvency. In such conditions, creditors may anticipate repayment without necessarily initiating the insolvency process.

All security interests must be properly publicized. An effective method of publication puts both existing and potential creditors on notice that a debtor company has fewer unencumbered assets available in which potential lenders might obtain meaningful interests. It also provides notice as to the order of priority for the distribution of assets if a company becomes insolvent. Filing or registration systems are comparatively more effective than inefficient systems that rely on possession as a form of security. The efficient enforcement of security interests is central to an effective secured transactions system. It also promotes both informal and judicially supervised workouts. An efficient system will minimize the need for judicial assistance wherever possible and expedite the enforcement process.

In the interaction between secured transactions and insolvency, the essential need is for insolvency law to respect the pre-existing priority rights of secured creditors. If the law poses unreasonable threats to secured lending, banks might increase transaction charges or restrict access to credit. In addition, when a company contemplating insolvency charges or mortgages assets to a creditor in exchange for identifiable value to the company, then as a general rule such charges or mortgages should not be voided by subsequent insolvency proceedings. Secured creditors should also be permitted to convert unsecured debts into secured debts, providing such transactions are completed substantially before the commencement of any insolvency proceedings. The law should provide that fraudulent or commercially unfair transactions that have a security component may be avoided. As a general rule, pre-petition interests should continue in post-petition proceeds, while postpetition grants of security should be permitted. Last, as a general rule, priorities in insolvency should be abolished.

Overall, East Asian economies would benefit from enacting insolvency laws that respect the pre-existing rights of secured creditors. However, in deciding to what extent exceptions may be permitted and how best to balance the needs of secured transactions and insolvency, law-makers in East Asia must first determine which approach they believe most appropriate.

\section{Creditor Rights and Insolvency in East Asia}

The appraisals given in Table 7 acknowledge extra-legal regulatory guidance for collaborative multi-creditor practice, for example in Hong Kong, Indonesia, Malaysia and Thailand. Regulators in these jurisdictions have attempted to instill informal out-of-court corporate workout practices similar to the well-established "London Rules," or "London Approach," promoted in the 1970s by the Bank of England as an alternative to formal court-based corporate insolvency proceedings

92. This is not universally accepted. For an example, see Schwartz, Security Interests, supra note 41, and Schwartz, Puzzle of Secured Debt, supra note 41 (questioning the economic efficiency of secured lending). 
involving multiple financial creditors. ${ }^{93}$ After the onset of the Asian financial crisis, such out-of-court workout procedures were applied more frequently than courtbased formal reorganizations, although the results were not consistent in all jurisdictions. ${ }^{94}$ Most jurisdictions also set up public administrative agencies to assist with the restructuring of domestic financial intermediaries and the disposal of nonperforming loans (NPLs).

In both Hong Kong and Singapore, systems and practice are well-established and generally sophisticated, but legislative reform has tended to lag both market practice and the willingness of the courts to intervene creatively in cases of corporate distress.

TABLE 7: DEVElopmENT OF EFFECTIVE INSOLVENCY SYSTEMS

\begin{tabular}{lllll}
\hline & $\begin{array}{l}\text { Legal } \\
\text { framework } \\
\text { for corporate } \\
\text { insolvency }\end{array}$ & $\begin{array}{l}\text { Corporate } \\
\text { insolvency } \\
\text { implementation }\end{array}$ & $\begin{array}{l}\text { Judicial } \\
\text { decision- } \\
\text { making and } \\
\text { enforcement }\end{array}$ & $\begin{array}{l}\text { Effective } \\
\text { insolvency } \\
\text { practitioners }\end{array}$ \\
\hline Cambodia & NA & NA & 1 & 1 \\
China $^{95}$ & $2 / 3$ & 1 & 1 & $1 / 2$ \\
Indonesia & $2 / 3$ & 1 & 1 & $1 / 2$ \\
Malaysia & 4 & 4 & 4 & 4 \\
Philippines & $2 / 3$ & $2 / 3$ & 2 & $2 / 3$ \\
South Korea & 4 & $3 / 4$ & 3 & $3 / 4$ \\
Taiwan & 3 & 3 & 3 & 3 \\
Thailand & 3 & $2 / 3$ & $2 / 3$ & $2 / 3$ \\
Vietnam & $1 / 2$ & $1 / 2$ & 1 & 1 \\
\hline Hong Kong & 4 & 5 & 5 & 5 \\
Singapore & $4 / 5$ & 5 & 5 & 5 \\
\hline
\end{tabular}

\section{Insolvency: Pre-1997 Overview}

Among the jurisdictions in this study, only Singapore had an insolvency regime adequate to deal with a high number of corporate failures at the opening of the Asian financial crisis. All other jurisdictions were hampered by antiquated or inadequate laws and procedures, many of which dated from colonial times. None maintained an effective formal corporate rescue procedure. Hong Kong and Malaysian corporate insolvency procedures were modeled on mid-20th century English law. Thai law dating from 1940 was influenced by English personal

93. Their precept is that financial creditors act in concert rather than any single creditor competitively advancing its position in ways that might provoke premature liquidation.

94. See supra note 65 and accompanying text. Informal practice has tended to be successful where the courts have stood ready to support a consensus reached among creditors and debtors, and where debtors or their controlling owners have been unable to challenge the enforcement of foreign judgments.

95. In regards to the recently enacted bankruptcy law that came into operation on June 1, 2007. 
bankruptcy laws, while Indonesian law was mainly Dutch in origin and dated from the late 19th century. South Korea's insolvency regime drew on Japanese law, which derived from German, Austrian, and U.S. principles and statutes. Taiwan's laws were also derived from Japan's laws and later, to a lesser extent from U.S. law, with the last pre-1997 amendments dating from the early 1980s. China's insolvency laws were written more recently, with bankruptcy provisions for state-owned enterprises (SOEs) enacted in 1986, and provisions for non-SOE enterprises with legal person status, in 1991. Vietnam's laws dated from 1994. These regimes used liquidationbased procedures, with the exception of Singapore. Cambodia still lacks an insolvency framework. For the most part, these insolvency laws were under-utilized.

Insolvency law in Hong Kong, Malaysia, and Singapore share the same basic structure of detailed liquidation or winding-up procedures and an abbreviated scheme of arrangement procedure for use in corporate rescue. The liquidation procedures in these jurisdictions are still the region's most efficient, although in need of modernization, but the scheme of arrangement procedure is cumbersome and expensive. Hong Kong and Malaysian procedures do not provide for an automatic stay on creditor claims in the absence of a winding-up order; Singapore operates a stay only on unsecured creditors. In none of these three jurisdictions are there mechanisms to force uncooperative secured creditors to the bargaining table. The result is that prior the Asian financial crisis, the procedure was rarely employed, although it saw more use in Singapore than in Hong Kong and Malaysia.. Singapore also introduced judicial management procedures in 1987 . These procedures may be initiated either by a debtor company or its creditors, and the procedure provides for an automatic stay while a judicial manager assumes the responsibility for running the company and proposing a plan of reorganization for creditor approval. ${ }^{96}$

The evolution of South Korea's insolvency regime has been more complicated. Until recently, the law had three parts, all dating from 1962, which concerned bankruptcy, composition, and reorganization. Rather than develop an insolvency solution, South Korea translated and enacted Japanese laws, so that the Bankruptcy Act was based on the Japanese Bankruptcy Act 1922, itself derived from German law. The Composition Act was based on a Japanese composition law taken from Austrian law; the Reorganization Act copied the Japanese Reorganization Act 1952, derived in turn from the U.S. Bankruptcy Act 1898. The composition law was triggered by a debtor's filing and only provided for temporary relief until creditors voted on a composition plan. The more complicated reorganization process was better suited for larger, public companies..

The Philippines civil law system has long-standing common law aspects, found also in some contemporary European jurisdictions, in that its supreme court decisions are binding as precedents. The pre-1997 Philippines insolvency law dated from 1909 and included a rarely used liquidation procedure and a corporate rescue suspension of payments process taken from Spanish law that was available only to solvent companies experiencing temporary cash flow problems. Any proposal for debt rearrangement required the full payment of debts, and so was rarely used. A rehabilitation procedure was introduced as an alternative to the inflexible suspension of payment process under a 1976 presidential decree, later amended in 1981. Rather

96. Lee Suet Lin Joyce, Is Singapore's Insolvency Regime Excessively Pro-Creditor?, 12 INT'L INSOLVENCY REV. 37 (2003) (discussing Singaporean corporate insolvency law). 
than giving jurisdiction for rehabilitation and suspension of payments to the judiciary, however, the amendment granted jurisdiction to the Securities and Exchange Commission (SEC). The rehabilitation procedure provided few rules and contained curiosities, such as providing that creditors were not obliged to approve a rehabilitation plan, and at times treating secured and unsecured creditors alike.

Indonesian and Thai insolvency law also provided for liquidation and suspension of payments procedures, which were also rarely used. Indonesian debtors are able to present a plan of composition even within the liquidation process. The suspension of payments process provides the debtor with additional time to finalize a repayment plan. Under Thai bankruptcy law, composition is possible either pre-petition or post-petition. An unusual aspect of the Thai Bankruptcy Act 1940 is that its presumption of insolvency appears to have been influenced by the acts of bankruptcy in $19^{\text {th }}$ century English law.

Taiwanese bankruptcy law dates from 1935 and provides for both liquidation and composition. The reorganization law under the Company Law, applicable to public companies, was similar to that in Korea. The reorganization law had not been amended in many years and was over-reliant on the court. The effectiveness of the old law has been criticized for its inconsistency "due in part to a lack of commercial viability on the part of the companies undergoing reorganization." 97 The lengthy reorganization process also enabled some companies to avoid bankruptcy by abusing the reorganization procedures. ${ }^{98}$

China was spared the most severe economic problems of the Asian financial crisis, and as of 1997 was the only jurisdiction in the study group whose bankruptcy laws had recently been promulgated. Nevertheless, at the time of the financial crisis, China was affected by domestic concerns resulting from the poor financial condition of its SOEs and state-owned banks. The insolvency framework in China at that time was an overlapping patchwork that included: a forty-three provision 1986 Bankruptcy Law for SOEs; eight provisions in Chapter XIX of the 1991 PRC Civil Procedure Law applicable to non-SOE enterprises with legal person status; judicial interpretations of these short laws, notably the 2002 interpretation by the Supreme People's Court; and most importantly, several policy decrees issued by the central government which are crucial in understanding the government's approach to insolvency issues. Although the number of insolvencies in China has been increasing, it is generally considered to be far lower than the number of insolvencies that would correspond to the true condition of most SOEs and banks, gauged by generally accepted accounting standards. A new bankruptcy law, under discussion for more than a decade, was finally enacted in August 2006 and is discussed below.

Vietnam enacted a bankruptcy law in 1993 that came into operation in the following year. Unlike China's bifurcated approach - with separate laws for SOEs and non-SOE legal person enterprises,-Vietnam had a unified law. The Vietnamese law was also more expansive than the former Chinese act in that it also applied to enterprises lacking legal personality (e.g, partnerships and sole proprietorships). . In practice, however, the law was cumbersome in application and rarely used. Its requirement that a debtor exhaust "all financial measures" before being eligible for bankruptcy effectively led to a two-year delay before a bankruptcy

97. Eric Tsai \& Hui-Erh Yuan, Taipei, China, in THE ASIA-PACIFIC RESTRUCTURING AND INSOLVENCY GUIDE 2006 154, 156 (2006).

98. Id. 
could be commenced. A new Vietnamese bankruptcy law came into operation in $2004 .^{99}$ Cambodia is currently considering enactment of its first insolvency law.

The profound impact of the 1997 crisis led to an immediate call to reform or replace archaic liquidation regimes and supplement them with modern corporate rescue procedures, including both formal court-based regimes and out-of-court and administrative procedures. Since the crisis, two waves of reform have crossed the region. The first included insolvency reforms in Indonesia, Malaysia, the Philippines, South Korea, Taiwan and Thailand. The second includes the new bankruptcy laws enacted in Vietnam in 2004 and China in 2006 and ongoing law reform efforts in Cambodia, Hong Kong, and Singapore, although the reform process in both China and Hong Kong began prior to mid-1997.

\section{Insolvency: Post-Financial Crisis Legal Reforms}

Thailand was among the states most severely affected by the 1997-98 financial crisis. A new chapter on business reorganization was added to the Bankruptcy Act in 1998 to facilitate corporate rescues. One reform provided for the appointment of a bankruptcy planner to manage the affairs of the debtor company and prepare a plan of reorganization. The new procedure was intended for large corporate debtors owing at least Bt10 million (US\$273,000) to their creditors and further provisions would be appropriate to create an efficient procedure for smaller debtors. Further amendments were made to the bankruptcy law in 2000 .

An important part of the Thai reforms was the establishment of a bankruptcy court with exclusive jurisdiction for such cases pursuant to the 1999 Act for the Establishment of and Procedure for Bankruptcy Court. The act was amended in 2004, while perceptions of the introduction of the bankruptcy courts have been varied. Initial views were positive, but concerns have increased as to the overall efficacy of these changes. There have been claims of inconsistency among individual courts; a fear that much of the expertise gained through the formation of the courts is lost when judges are rotated into other courts; an increasing backlog of cases; and there are concerns that corruption and fraud may be affecting the courts' work. ${ }^{100}$ At present, these concerns appear to have eased somewhat and there is a re-emerging sense that the judicial reforms were for the best.

Indonesia was more severely impacted by the 1997 crisis. In 1998, the Bankruptcy Ordinance was amended by a Government Regulation in Lieu of Law. Indonesia established a Commercial Court after the crisis to hear bankruptcy cases, but according to one commentator the court "has been beset by concerns of corruption and inconsistent application of the Bankruptcy Act"101 and "[t]he Indonesian Corruption Watch reports of corruption in the legal system is staggering." "102 Many abuses have been publicized, with cases involving Canadian insurer Manulife and the Indonesian-controlled group APP (Asia Pulp \& Paper) the

99. See Charles Booth, Drafting Bankruptcy Laws in Socialist Market Economies: Recent Developments in China and Vietnam, 18 COLUM. J. ASIAN L. 93 (2004).

100. Vassiliou, supra note 66, at 21.

101. Lampros Vassiliou, The Asian Recovery: Progress and Pitfalls, Presented at the Global Forum on Insolvency Risk Management, Washington, DC (Jan. 28-29, 2003) at 6.

102. Id. at 7. 
most well-known, having been the subject of much controversy and media coverage. However, the IMF and ADB funded a group of local lawyers and judges known as "Team 7" to address such problems and evaluate the Commercial Court's decisions. ${ }^{103}$ Further amendments to Indonesian law were enacted in 2004.

South Korea has made the most significant changes to the formal insolvency laws of all the jurisdictions in this study. Its corporate sector, especially the closelycontrolled chaebol conglomerates, was traditionally highly-leveraged, which proved an immediate burden in the light of a post-crisis withdrawal of available credit. South Korea agreed to enact substantial changes in law at the instigation of the IMF and World Bank in the form of amendments to its tripartite insolvency legislation covering liquidation, composition and reorganization. U.S. bankruptcy law influenced many of these changes. Among notable reforms was the inclusion of creditor committees in composition proceedings and management committees in reorganizations, while the time limit for reorganizations was halved from twenty to ten years. Many changes were intended to expedite reorganization procedures. Further amendments were made in 2000 and 2001, the latter including formalizing an out-of-court Workout Accord in the reorganization legislation to enable creditors to file proceedings to bind foreign creditors. A more recent major change to insolvency law was a Debtors' Rehabilitation and Bankruptcy Act (DRBA), which came into effect on April 1, 2006, and for the first time consolidated the three parallel insolvency acts. The new act further expedites corporate rescue processes, expands the reorganization system and abolishes the Composition Act. The task for South Korea may now be to ensure that its new legal framework is properly implemented, for which further practitioner training is likely to be necessary.

Amendments to Philippines law were made in July 2000. Among the most significant changes was the transfer of jurisdiction for rehabilitation and suspension of payment cases from a state regulatory agency to the courts. ${ }^{104}$ Interim Rules of Procedure for Corporate Rehabilitation were promulgated in December 2000, in far more detailed form than the procedures under a prior Presidential Decree. Suspension of payment cases and corporate rehabilitation have become more common since the financial crisis, but delays remain a problem under the new regime obtaining post-petition financing has remained difficult. Other reforms are currently under discussion, notably a Corporate Recovery and Liquidation Act and a Corporate Recovery Act. It is hoped that the former includes a provision for fasttrack rehabilitation but congressional passage of these bills has been slow. The goal for the Philippines is also to increase the institutional capacity of the judiciary and of insolvency practitioners. Transferring jurisdiction for insolvency cases from the SEC to the courts is understandable, but it ensures that the Philippines is the sole jurisdiction in the study core where administrative and judicial enforcement capacity have decreased since the financial crisis. Another goal for the Philippines will be to better protect the rights of secured creditors.

A reform of the Taiwanese Company Law in 2001 streamlined the reorganization procedures. These were the first major reforms to the procedures in roughly thirty years. Among the changes to the law were reducing the length of the reorganization process and requiring that companies using the procedures "be

103. Id. at 35 .

104. See supra Part V(C)1. 
capable of being revived through reorganisation." 105 It has been noted that several successful reorganizations have recently been carried out and that the changes have enhanced the viability of the new law as a restructuring tool and reduced the incentives for debtors to abuse the reorganization process. ${ }^{106}$ Further changes to the insolvency laws are also being considered, including a proposal to unify the bankruptcy and reorganization laws into a single code.

In August 2006, China enacted a new insolvency law that came into operation in June 2007. This new law is the result of an insolvency law reform process that dates back to 1994 . This law applies to all legal person enterprises and unifies the existing patchwork of bankruptcy laws, decrees, and judicial interpretations. This new law radically improves both the liquidation and corporate rescue processes. At the heart of these reforms is the introduction of an office of the professional administrator to replace the current inefficient liquidation team model. The new law includes a detailed corporate rescue process that draws heavily on Chapter 11 of the U.S. Bankruptcy Act (for example, providing for post-petition financing and a limited cramdown). These procedures will allow for reorganizations led either by the administrator or a debtor-in-possession (under the supervision of the administrator).

The main substantive issue delaying the enactment of the new law was a conflict as to how to resolve the interests of secured creditors and employees in cases where company funds prove insufficient to meet wages in full. A compromise was reached providing that secured creditors will have priority over all workers' claims arising after August 27, 2006, but that certain wage, medical, and insurance claims of workers arising before that date will have priority over the claims of secured creditors. Another controversial issue during the drafting process was whether SOEs should be made subject to the new law. The new law provides that special matters regarding the bankruptcy of SOEs shall no longer continue to be handled under State Council regulations. Time will tell whether that will be the case.

In reforming its insolvency law, Vietnam was interested in China's approach to similar issues. When both Vietnam and China issued new draftlaws in 2002, the former was at an earlier stage of development. However, Vietnam avoided the contentious delays that occurred in China and enacted its law in 2004. This abolished the former requirements that a debtor must first exhaust "all financial measures" to become eligible for bankruptcy relief, and represents a significant reform. However, in comparison to China, Vietnam's reform approach was gradualist, lacks a "driver" of the new legal process (i.e., does not have an official equivalent to the Chinese administrator), and has fewer checks and balances.

Attempts at Hong Kong insolvency law reform pre-date the 1997 financial crisis. In 1996 the Hong Kong Law Reform Commission set out the framework for a new regime, by which a qualified specialist called a "provisional supervisor" would after commencement of the process take control of the company and be responsible for drafting a proposal for creditor agreement. The first draft bill was gazetted in 2000 , and offered many advantages over current law, but a primary flaw has been a proposal that employees' salaries be paid in full or sufficient funds placed in trust for

105. Tsai \& Yuan, supra note 97 , at 156.

106. Id. 
the purpose. ${ }^{107}$ Fortunately, in a line of cases beginning in 2002 , the judiciary was receptive to the use of provisional liquidation as a mechanism to facilitate corporate rescue. However, the use of provisional liquidation to assist with corporate rescue was narrowly re-interpreted in the recent case of Re Legend International Resorts $L t d$, which required that a company's assets first be in jeopardy for a provisional liquidator to be appointed. ${ }^{108}$ The enactment of a provisional supervision regime in the foreseeable future is quite unlikely. ${ }^{109}$

Singapore's insolvency regime is currently the most comprehensive of the study group. For more than five years, schemes of arrangements have proven more popular than judicial management cases. Among the reasons are that a stay on unsecured creditor action in the scheme of arrangement procedure gives the debtor company sufficient time to proceed to propose such a scheme; it can remain in possession of assets and equipment; and less adverse publicity and commercial stigma appears to arise in relation to a scheme of arrangement than from many judicial management cases. As with Hong Kong and Malaysian law, a weakness of Singapore's model is the bifurcation of corporate insolvency procedures in company law, and the personal insolvency procedures in bankruptcy law. Singapore is considering the enactment of unified legislation to address this problem, but this will not take place in the short term.

\section{Insolvency: Post-Financial Crisis Out-of-Court Reforms}

Although legal insolvency reforms received much attention due to the needs created by the Asian financial crisis, the time taken to enact and implement any such legislation is inevitably protracted. While legislative reforms were first considered, other efforts began to save companies whose businesses could create value for creditors and other stakeholders. These efforts led to two types of reforms, the first being the promulgation of out-of-court workout procedures based on the London Approach. ${ }^{110}$ These included the Bangkok Approach, Malaysia's Corporate Debt Restructuring Committee (CDRC), the Hong Kong Approach, the Jakarta Initiative, and the Workout Accord in South Korea. In contrast to the general experience in Europe, this semi-formal approach has been successful in cases where the parties involved are overwhelmingly of a single domicile. Still, they have been only modestly helpful in Asia's many post-1998 cross-border multi-creditor restructurings, despite a large number of such cases being managed by banks operating in Hong Kong. ${ }^{111}$

More radically, where national banking sectors were severely affected by delinquent loans, the second alternative provided for establishment of administrative

107. See Philip Smart \& Charles Booth, Reforming Corporate Rescue Procedures in Hong Kong, $1 \mathrm{~J}$. OF CORP. L. STUD. 485 (2001); Booth, supra note 99.

108. [2006] HKCA 67; CACV000207/2005, Mar. 1, 2006.

109. See Charles Booth, The Race of Two Tortoises: Insolvency Law Reform in Hong Kong and China, CHINA L. REP., Nov. 2006, at 3.

110. See supra note 93 and accompanying text, but note that the "the effectiveness of such semivoluntary arrangements has been eroded by the growing use of loan sales and other forms of credit risk transfer"; see BERRY HSU ET AL., FINANCIAL MARKETS IN HONG KONG: LAW \& PRACTICE 154 (2006). Outside Asia, the practice has influenced the recent development of protocols for the settlement of credit default swaps.

111. Id. 
asset management agencies to assist with the restructuring and disposal of NPLs, including the Indonesian Bank Restructuring Agency (IBRA), Malaysia's Pengurusan Danaharta Nasional Bhd (Danaharta), and the Thai Asset Management Company (TAMC). For the most part, these entities were created as part of emergency measures and several are in the process of being shut down. ${ }^{112}$

Hong Kong established its Hong Kong Approach to Corporate Difficulties in 1999, modeled on the London Approach, with the backing of the self-regulated Hong Kong Association of Banks and the government's Hong Kong Monetary Authority.

South Korea established an out-of-court workout process in June 1998, in the form of a Workout Accord among financial intermediaries. The process was imperfect, though, as it excluded foreign creditors and provided no priority for postcommencement financing. In 2001 the Workout Accord procedure was promulgated as part of the reorganization law to address these two problems and formally expired on December 31, 2005. The Korean Asset Management Company (KAMCO) assisted in resolving the commercial banking sector's sizeable accumulation of NPLs. Unlike similar Asian asset management companies (AMCs), KAMCO was not a temporary entity established to deal with the 1997 crisis, and had been formed in 1962. Indonesia established the Jakarta Initiative to assist with out-of-court restructuring and set up IBRA to deal with the impaired assets of Indonesian financial intermediaries. IBRA became very substantial, and was the largest national landowner before its dissolution in 2004. ${ }^{13}$ Its results were less effective than those of state-sponsored AMCs elsewhere, notably KAMCO or Danaharta, in particular due to a policy of acquiring distressed assets at inflated balance sheet prices rather than establish a realistic market value-even though the payments made to the transferor banks were not necessarily of the same order.

Malaysia established CDRC to assist with informal out-of-court rescues and an asset management entity (Danaharta) to assist with problems encountered by the financial sector. Danaharta had strong powers of enforcement and its results are still viewed as important in addressing post-crisis problems in Malaysia.

In 1998, the Bank of Thailand established an informal out-of-court restructuring procedure for financial creditors known as the Bangkok Approach, headed by the Corporate Debt Restructuring Advisory Committee. TAMC was created pursuant to emergency legislation in June 2001 to assist in the disposal of financial sector NPLs.

China established four AMCs to address accumulated NPLs at each of the largest state-owned commercial banks. The first, China Xinda Asset Management Company (Cinda) for Construction Bank of China and China Development Bank, was formed in April 1999. It was followed by China Huarong Asset Management Corporation for Industrial and Commercial Bank of China, Dongfang Asset Management Company (Oriental) for Bank of China, and China Great Wall Asset Management Company for Agricultural Bank of China. Regional AMCs were also

112. The forerunner model of these entities was the U.S. Resolution Trust Corporation, which from 1989-95 acted as a federal asset disposal conduit for failed savings and loan and other housing finance organizations.

113. Vassiliou, supra note 101 , at 35. 
established, including the important Guangdong Guangye Asset Management Company.

Like China, Vietnam established AMCs connected to the commercial banks to dispose of NPLs. In addition, Vietnam established a national Debts and Assets Trading Company managed by the Ministry of Finance.

Taiwan also has established AMCs to assist with the disposal of NPLs through the promulgation of the Financial Institutions Merger Act of 2000.

\section{Interaction between Creditor Rights and Insolvency}

A theme of this study is that effective insolvency regimes go hand-in-hand with effective secured transaction regimes. This parallel development of secured transaction laws is absent from most of the jurisdictions considered. The overall implementation of insolvency regimes throughout the region would benefit from the improvement or introduction of effective secured transactions systems, for it is within insolvency cases that the integrity of secured transactions and the rights of secured creditors are fully tested.

The English system of company law adapted in Hong Kong, Malaysia, and Singapore puts secured creditors in a relatively strong position in insolvency matters, and there is thus a high level of predictability as to the rights of secured creditors in these three jurisdictions. Secured creditors act outside a liquidation and are not subject to a general stay against creditors. Unless agreed otherwise, they also act outside any scheme-of-arrangement process. It is only in judicial management cases in Singapore that secured creditors are made subject to the general stay.

\section{TABLE 8: COMPATIBILITY OF CREDITOR RIGHTS AND INSOLVENCY SYSTEMS}

\begin{tabular}{|c|c|c|c|}
\hline & $\begin{array}{l}\text { Principal source and } \\
\text { system of current law }\end{array}$ & $\begin{array}{l}\text { Form of legal } \\
\text { transplant }\end{array}$ & $\begin{array}{l}\text { Compatibility } \\
\text { of systems } \\
\text { relating to } \\
\text { creditor rights } \\
\text { and those } \\
\text { permitting } \\
\text { secured } \\
\text { transactions }\end{array}$ \\
\hline Cambodia & French civil & Imposition & NA \\
\hline China $^{115}$ & $\begin{array}{l}\text { Mixed (German civil; } \\
\text { Socialist) }\end{array}$ & Adoption & $1 / 2$ \\
\hline Indonesia & Dutch civil & Imposition & $1 / 2$ \\
\hline Malaysia & English common & Imposition & $3 / 4$ \\
\hline
\end{tabular}

114. For guidance only: questions of legal inheritance or transplant are beyond the direct scope of this article. The indications given in Table 8 take no real account of mixed jurisdictions, or of what has been termed "chthonic law," whether ancient or contemporary. See H. PATRICK GLENN, LEGAL TRADITIONS OF THE WORLD: SUSTAINABLE DIVERSITY IN LAW 58-114 (2004).

115. In regard to the recently enacted bankruptcy law that came into operation in June 2007. 


\begin{tabular}{|c|c|c|c|}
\hline Philippines & Mixed (Spanish civil; U.S.) & Imposition & $1 / 2$ \\
\hline South Korea & German civil & Mixed & $3 / 4$ \\
\hline Taiwan & German, Japanese civil & $\begin{array}{l}\text { Imposition / } \\
\text { adoption }\end{array}$ & $3 / 4$ \\
\hline Thailand & French civil & Adoption & $1 / 2$ \\
\hline Vietnam & $\begin{array}{l}\text { Mixed (French civil; } \\
\text { Socialist) }\end{array}$ & $\begin{array}{c}\text { Imposition / } \\
\text { adoption }\end{array}$ & 1 \\
\hline Hong Kong & English common & Imposition & $4 / 5$ \\
\hline Singapore & English common & Imposition & $4 / 5$ \\
\hline
\end{tabular}

In China, the rights of a secured creditor historically have depended upon whether a bankruptcy case is entered pursuant to government policy decrees or bankruptcy laws, though the new bankruptcy law claims to bring this distinction to an end. Under the old regime, there was a traditional priority scheme in the bankruptcy laws whereby employee claims ranked after those of secured creditors. In contrast, in policy bankruptcies, secured creditors could lose priority in land-use rights and other secured assets to employees, so as to assist the latter with resettlement and other entitlements. However, as noted above, under the recently agreed compromise, the new Chinese bankruptcy law provides that secured creditors will have priority over all workers' claims arising after August 27, 2006, but that certain wage, medical, and insurance claims of workers arising before that date will have priority over the claims of secured creditors. Although secured creditors are subject to a stay in liquidations and reorganizations, they retain priority in payment to the extent of their collateral.

In summary, China, Indonesia, the Philippines, and Vietnam adopt the U.S. approach by which secured creditors are subject to an automatic stay in both liquidations and reorganizations. In contrast, in South Korea, Singapore, and Thailand, secured creditors are subject to a moratorium in reorganizations, but not in liquidations or compositions. Last, secured creditors of companies in Hong Kong, Malaysia, and Taiwan may act unilaterally outside both bankruptcy and reorganization. In jurisdictions where secured creditors are subject to an automatic stay, the courts have rarely applied principles of adequate protection when those creditors seek to be exempt. ${ }^{116}$ In the Philippines, less account is taken than elsewhere of the views of secured creditors in the preparation and sanction of reorganization plans. In some instances, secured creditors have been required to share pari passu with unsecured creditors.

Two main areas of law in the interaction of secured creditors and insolvency needing improvement in most jurisdictions are first, protection for secured creditors seeking exemption from the automatic stay; and second, limiting employee priority in claims over properly established secured interests. 


\section{Summary}

In an immediate post-crisis review of regional insolvency law reforms, the ADB found that the number of insolvency cases remained low in Indonesia, Malaysia, the Philippines, South Korea, and Thailand, despite rising from pre-crisis levels. Indonesia, the Philippines, and Thailand were identified as having "extraordinarily low" liquidations, and Indonesia and Thailand were identified as jurisdictions in which the use of new formal reorganization laws was surprisingly low. Liquidations were most numerous in South Korea and Malaysia, with Malaysia having more. South Korea had by far the greatest number of reorganizations, but lower than might have been predicted based on national output losses in 1997-98.

The review also found that out-of-court processes were used far more often than formal insolvency laws except in South Korea, where their overall use was also "surprisingly low." 117 Data for the study were obtained from observations up to mid1999, but subsequent anecdotal observations support these findings. It remains difficult to obtain accurate insolvency case data from most jurisdictions in Asia, and harder still to locate accurate assessments of out-of-court workouts. However, case data may not be the sole benchmark of success. One benefit of enacting formal corporate rescue laws is that by setting outvoting minimums and implementation requirements for reorganization plans, a framework for extra-judicial negotiations is created that addresses problems of the type caused by intransigent holdout creditors, both before and since the region's financial crisis. If recalcitrant creditors currently use such tactics, a debtor or creditor may threaten formal insolvency proceedings so as to cause the holdout creditor to be outvoted.

The ADB study demonstrates that the promulgation of new insolvency laws is only part of achieving an effective insolvency system. Although a new law may be modern in design and enacted to facilitate corporate rescue, its impact will take time to discern. In contrast, the benefits from enabling out-of-court rescue processes have typically been more immediate.

Of the core jurisdictions discussed in this article, implementation of an effective corporate insolvency regime is best achieved in Singapore and Hong Kong, which are also the jurisdictions that have made the least changes to their laws since the 1997-98 crisis. Hong Kong is unusual in that while it lacks an effective formal corporate rescue law, it scores highly, largely due to the adaptation of the provisional liquidation procedure and the creativity of judiciary and insolvency practitioners in crafting out-of-court corporate rescues. The main goals for both Hong Kong and Malaysia remain the need to enact modern corporate rescue systems and to update aspects of liquidation procedures. The latter is also relevant for Singapore and most other countries examined here. It is expected that Cambodia will soon enact a modern insolvency law.

The demand following the enactment of formal insolvency laws is to stimulate human resources through greater judicial competence as well as training effective insolvency practitioners. Specialized courts or benches are valuable but experiences in Indonesia and Thailand demonstrate that the creation of such courts is not a panacea. It is important for the judiciary to strive for consistency, and to eliminate corruption and the trading of influence. Professional and judicial training are crucial in this process. Another important feature of strengthening the implementation of

117. See Report on Insolvency Law Reforms, supra note 65, at 10-11, 70-75. 
the law is the development of a government agency to regulate insolvency processes. The Official Receiver's Office in Hong Kong and the Official Assignee's offices in Malaysia and Singapore each perform this function effectively. It is also crucial for practitioners to discuss regularly contemporary insolvency developments among themselves and with national regulators. Hong Kong currently offers a good example of such interaction, which contributes to the overall effectiveness of the sector. Lawyers and accountants meet regularly for training sessions run by the Insolvency Interest Group, housed in the Hong Kong Institute of Certified Professional Accountants. The latter runs insolvency training courses including an advanced diploma course that is recognized by the Official Receiver's Office. Such arrangements could serve as a model for the region.

The activities of the World Bank and UNCITRAL show that there is no single set of provisions for an effective insolvency regime. Nonetheless, three issues have commonly caused difficulties in the implementation of new insolvency laws in the region. First, the granting of over-generous priority or preference to employees can lead to an unconstructive response by secured creditors and ultimately adversely affect bank lending and secured transactions. Second, it may be a serious disincentive for many officers and directors of distressed companies to be replaced immediately by an outside administrator, especially among smaller family-controlled companies that are seeking relief from creditors. Last, the commencement criteria should be as clear as possible, for example, avoiding balance sheet insolvency tests that may rely on imperfect accounting standards.

\section{CONTRACT ENFORCEMENT AND DisPute RESOLUTION}

The most critical neglect throughout the region is in enforcement and implementation, with the partial exceptions of Hong Kong and Singapore. According to Haselman, Pistor, and Vig:

The major function attributed to law is that it empowers creditors to enforce their contracts. Effective legal institutions reduce the risk of lending and therefore result in greater lending volume in an economy as a share of GDP. Implicit in this view of how law affects economic outcome is that all actors in the economy benefit from better law. ${ }^{118}$

This may suggest that the law matters less than its enforcement. Both theory and experience support this position. Coase was first to describe the importance of delineation and enforcement of commercial contracts, in analyses based upon observations of industrial practice. ${ }^{119}$ In an environment of imperfect markets with real transaction costs, parties will seek efficient results through contracting. Unfortunately, transaction costs extend to the expense of enforcement, without which contracting cannot produce solutions to market imperfections nor lead to stable long-term outcomes. Rather, contracting will tend towards sub-optimal instantaneous transactions such as barter, which is in part a state from which the least developed members of the study core have recently emerged.

118. Haselmann, Pistor \& Vig, supra note 38.

119. See Coase, supra note 43; R. H. Coase, The Problem of Social Cost, 3 J. L. \& ECON. 1 (1960). 
The enforcement of contracts requires a system of governance capable of producing, applying, and policing effective solutions. Part II of this article showed that a range of such systems may be theoretically capable of producing this result, and history has provided many disparate examples. Enforcement of contracts is not synonymous with the existence of the rule of law, but just one component of a system that can be so described. The rule of law is not a precondition for a market economy, despite generally being considered an important factor in economic development and highly conducive to financial market development. Yet a governance system that enforces contracts and resolves commercial disputes in a credible and predictable manner is essential to a basic market economy, as well as allowing financial markets to develop beyond the simplest single instantaneous transactions. This is important for institutional concerns such as the enforcement of financial contracts, efficient insolvency, and collateral systems, and dispute resolution procedures. In this context, mechanisms for contract enforcement and resolving commercial disputes may also be more important than specific laws.

There are four further concerns. First, broadening the availability of real property ownership and mechanisms to support its use, especially relating to enforcement and commercial dispute resolution mechanisms. Second, the need more simply to delineate the provisions for secured transactions, in particular to provide for security interests in intangible property. Third, the development of effective registration systems to cover a range of assets, including real property, security, and intangibles, and to simplify the use and availability of collateral and its enforcement, leading to reductions in transactions costs. Last, where judicial systems for enforcement and dispute resolution are ineffective, the support of appropriate mechanisms for creditor and debtor self-assistance deserve, provided that they are transparently fair and just. This includes encouraging greater use of commercial arbitration.

The foregoing Tables 2, 5, 7, and 8 show that most jurisdictions addressed in this Article have developed generally acceptable laws relating to creditor rights and insolvency but have failed fully to reform their collateral and secured transaction regimes. At the same time, where such insolvency or collateral laws have been enacted, few jurisdictions have been effective in their implementation and enforcement. This is the concern to which legislative and administrative attention needs to be devoted and which clearly demonstrates the linkage between effective governance, economic, and legal systems and property, collateral, and creditor rights in East Asia. 